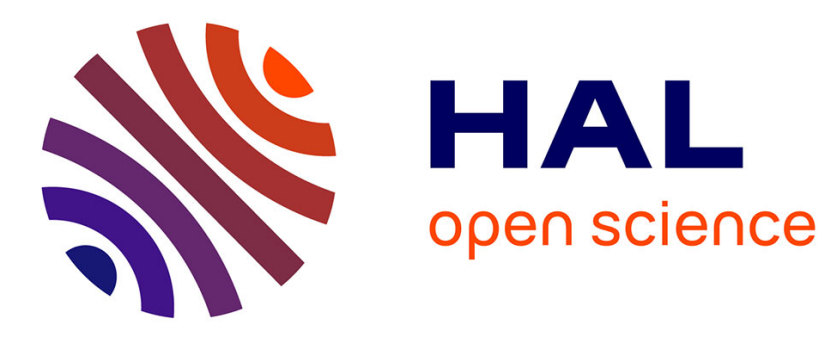

\title{
The gonadotropins: Tissue-specific angiogenic factors?
}

\author{
K. Reisinger, N. Baal, T. Mckinnon, K. Münstedt, M. Zygmunt
}

\section{To cite this version:}

K. Reisinger, N. Baal, T. Mckinnon, K. Münstedt, M. Zygmunt. The gonadotropins: Tissuespecific angiogenic factors?. Molecular and Cellular Endocrinology, 2007, 269 (1-2), pp.65. 10.1016/j.mce.2006.11.015 . hal-00531904

\section{HAL Id: hal-00531904 https://hal.science/hal-00531904}

Submitted on 4 Nov 2010

HAL is a multi-disciplinary open access archive for the deposit and dissemination of scientific research documents, whether they are published or not. The documents may come from teaching and research institutions in France or abroad, or from public or private research centers.
L'archive ouverte pluridisciplinaire HAL, est destinée au dépôt et à la diffusion de documents scientifiques de niveau recherche, publiés ou non, émanant des établissements d'enseignement et de recherche français ou étrangers, des laboratoires publics ou privés. 


\section{Accepted Manuscript}

Title: The gonadotropins: Tissue-specific angiogenic factors?

Authors: Reisinger K., Baal N., McKinnon T., Münstedt K., Zygmunt M.

PII: $\quad$ S0303-7207(07)00050-0

DOI: $\quad$ doi:10.1016/j.mce.2006.11.015

Reference: $\quad$ MCE 6616

To appear in: $\quad$ Molecular and Cellular Endocrinology

Received date: 24-6-2006

Revised date: $\quad 1-11-2006$

Accepted date: $\quad 1-11-2006$

Please cite this article as: Reisinger, K., Baal, N., McKinnon, T., Münstedt, K., Zygmunt, M., The gonadotropins: Tissue-specific angiogenic factors? Molecular and Cellular Endocrinology (2007), doi:10.1016/j.mce.2006.11.015

This is a PDF file of an unedited manuscript that has been accepted for publication. As a service to our customers we are providing this early version of the manuscript. The manuscript will undergo copyediting, typesetting, and review of the resulting proof before it is published in its final form. Please note that during the production process errors may be discovered which could affect the content, and all legal disclaimers that apply to the journal pertain. 
The gonadotropins: tissue-specific angiogenic factors?

Reisinger K., Baal N., McKinnon T., Münstedt K., Zygmunt M.

Correspondence: Marek Zygmunt, MD, $\mathrm{PhD}$

Department of Obstetrics and Gynecology, University of Giessen

Klinikstrasse 32, 35385 Giessen, Germany

Phone: +49 6419945113

Fax: $\quad+496419945109$

E-mail: marek.t.zygmunt@gyn.med.uni-giessen.de 


\section{Abstract}

The gonadotropins, whose members are human chorionic gonadotropin (hCG), lutenizing hormone (LH) and follicle-stimulating hormone (FSH) are a well characterized hormone family known to regulate reproductive functions in both females and males. Recent studies indicate that they can modulate the vascular system of reproductive organs. It was shown that gonadotropins not only influence the expression of Vascular Endothelial Growth Factor (VEGF) and both its receptors VEGFR-1 and -2, but also modulate other ubiquitously expressed angiogenic factors like the angiopoietins and their receptor Tie-2, basic Fibroblast Growth Factor or Placental-derived Growth Factor. Some recent data indicates a possible direct action of gonadotropins on endothelial cells. Thus, the gonadotropins act as tissue-specific angiogenic factors providing an optimal vascular supply during the menstrual cycle and early pregnancy in the female reproductive tract as well as in testis. In pathological conditions (e.g. preeclampsia, intrauterine growth restriction, ovarian hyperstimulation or endometriosis) these tightly regulated interactions between the gonadotropins and the ubiquitous angiogenic factors appear to be disturbed. The intent of this short manuscript is to review the current knowledge of the regulatory role of the gonadotropins in vasculo- and angiogenesis. We also review angiogenic actions of thyroid-stimulating hormone (TSH), a glycoprotein closely related to gonadotropins which display strong gonodal actions.

\section{Keywords}

Gonadotropins, hCG, angiogenesis, female reproductive organs 


\section{Introduction}

The main physiological functions of gonadotropins in the regulation of steroidogenesis in the ovary and testis are well understood. In recent years several studies were published describing some novel functions of these hormone-releasing factors indicating their possible involvment in the regulation of vascular development.

The formation of blood vessels plays an essential role in the female reproductive system. In order to cope with their physiological functions reproductive organs develop sophisticated vascularity and receive some of the highest blood flow and metabolic rates in the body (Adair et al., 1990; Reynolds and Redmer, 1995). During the menstrual cycle angiogenesis takes place both in the ovaries and uterus. In the case of pregnancy the corpus luteum, placenta, and uterus are also affected. On the other hand impaired blood vessel formation may lead to severe pregnancy-related disorders, whereas increased blood vessel formation might be involved in pathological situations like endometriosis or neoplasia. The aim of this short manuscript is to review the current knowledge of the regulatory role of the gonadotropins in vasculo- and angiogenesis. 


\section{Blood vessel formation}

The vascular system develops through two distinct processes: vasculogenesis and angiogenesis. During vasculogenesis, mesoderm-derived precursor cells form a primitive vascular network through a process of differentiation and proliferation. The primary vascular plexus is remodelled to a complex circulation system in the course of angiogenesis by creating vascular sprouts from preexisting microvessels. Until recently adult or postnatal blood vessel formation was described as a result of angiogenesis. Recent investigations have also shown that circulating endothelial precursor cells, e.g. from the bone marrow, can contribute to adult angiogenesis as well (Asahara et al., 1997; Carmeliet and Jain, 2002).

The newly formed blood vessels confirm an organ-specific phenotype, growth properties and functions (Simionescu and Simionescu, 1988). Thus, endothelial cells in the kidney, which are involved in liquid filtration, display a leaky or fenestrated phenotype supported by the surrounding epithelial cells. In contrast, endothelial cells building the blood-brain barrier display a (so-called) “continuous” phenotype characterized by high impermeability and high electrical resistance.

The adaptation and formation of the vascular system is controlled by ubiquitously expressed angiogenic factors. Recent reports indicate that there are organ-specific endothelial cell mitogens and modulators (e.g. the endocrine gland-derived vascular endothelial growth factor), shaping angiogenic responses in distinct tissues. "These findings suggest that, although signalling of ubiquitous factors may be a rate-limiting step in a wide variety of circumstances, local regulatory pathways modulate endothelialcell growth and function in a tissue- or organ-specific manner. Therefore, a novel class of tissue-specific regulators is likely to exist” (LeCouter et al., 2002). 


\subsection{Angiogenic Factors}

Numerous regulatory factors of the complex angiogenic process have been identified. They comprise peptide growth factors, hormones, cytokines as well as chemical or physical stimuli (reviewed in Zygmunt et al., 2003). This review will concentrate on two groups of angiogenic factors, which are both influenced by the gonadotropins.

\subsubsection{Vascular endothelial growth factor - family}

The vascular endothelial growth factor (VEGF, also referred to as VEGF-A) is viewed as a prime regulator of blood vessel growth during vasculogenesis and angiogenic sprouting (Yancopoulos et al., 2000). VEGF is known for its ability to induce vascular permeability, to promote endothelial proliferation as well as migration, and to act as a critical survival factor for endothelial cells (Dvorak et al., 1995; Ferrara, 1999). Other members of the VEGF family were identified based on their homology to VEGF, like VEGF-B, -C, -D and -E. They have overlapping abilities to interact with a set of receptor tyrosine kinases. The VEGF receptor-1 (VEGFR-1, originally known as Flt-1) and VEGF receptor-2 (VEGFR-2, originally known as KDR/Flk-1) are predominantly involved in mediating the effects of VEGF (Matsumoto and Claesson-Welsh, 2001). Whereas VEGFR-1 may mainly act in a negative fashion by inhibiting VEGFR-2 signalling or by functioning as a decoy receptor (Rahimi et al., 2000; Hiratsuka et al., 1998), VEGFR-2 is thought to mediate the major permeability, growth, anti-apoptotic and migration stimulating effects of VEGF. Although VEGF and VEGFR-2 are only expressed at relatively low levels in the adult, they may be markedly and rapidly upregulated by tissue and situation-specific factors. While VEGF is secreted by various 
different cell types, VEGFR-2 expression is largely restricted to vascular structures with exceptions in the female reproductive system.

\subsubsection{Angiopoietins}

Members of the VEGF-family act in concert with the angiopoietins, which are critically involved in the formation and rebuilding of the vasculature during vasculogenesis and angiogenesis. Four members of the angiopoietin (Ang) family are identified so far, although Ang-3 and -4 may represent widely diverged counterparts. All angiopoietins are ligands for Tie-2. Tie-2 is a receptor tyrosine kinase, which, similar to the VEGF receptors, is selectively expressed by endothelial and hematopoietic cells. The previously described receptor Tie-1 remains an orphan receptor, as the search for its ligands has remained unsuccessful. Ang-1 is mainly involved in stabilization of premature vessel structures (Suri et al., 1998; Hayes et al., 1999). Conversely, acting as a Tie-2 antagonist, Ang-2 mediates a key destabilizing signal by initiating angiogenic remodelling (Yancopolous et al., 2000). 


\section{Gonadotropins}

The angiogenic properties of the gonadotropins can be described in relation to the known characteristics of the hormone family. Gonadotropins bind to classical Gprotein-associated seven-transmembrane domain receptors (Minegishi et al., 1991; Kelton et al., 1992). The receptors are unique in having a large extracellular domain, comprising nearly a half of the receptor protein, which is involved in hormone recognition and binding (Tilly et al., 1992; Nagayama et al., 1991). The receptor mRNAs are submitted to extensive alternative splicing, whereby the physiological function of these isoforms is yet to be clarified in detail (Licht et al., 2003).

\section{hCG}

HCG is synthesized and secreted by the placental syncytiotrophoblast, and to a lesser extent by the cytotrophoblast from the time of implantation. A variety of trophoblast and non-trophoblast tumors also secrete hCG into the circulation (Odell, 1977).

The hCG/LH receptor was identified as a member of the rhodopson/ $\beta 2$-adrenergic receptor subfamily of the G-protein coupled receptors (Gether, 2000; Bockaert et al., 1999). The mature form of the receptor, present at the cell surface, is a glycoprotein with an apparent molecular mass of $85-95 \mathrm{kD}$ which arises during maturation in terms of extensive glycolysation and transport of a 60-75 $\mathrm{kDa}$ precursor that is localized in the endoplasmatic reticulum. Within the female reproductive tract LH/hCGR has been reported to be present in humans as well as a variety of other mammals, including rats, mice, rabbits, cows, and pigs (Ascoli et al., 2002). In the ovary, expression of the hCG/LHR occurs in the theca cells, interstitial cells, differentiated granulosa cells, and lutheal cells. In nongonadal tissues of the female reproductive system expression was 
detected in pregnant and non pregnant uterus, fallopian tube, amnion, chorion, decidua, umbilical cord, placenta (Reshef et al., 1990; Dufau, 1998), and, furthermore, in human fetal nongonadal organs (Abdallah et al., 2004), in adult brain (Lei et al., 1993) and skin (Pabon et al., 1996).

In the male, hCG/LH receptor is expressed in Leydig cells during fetal development, transiently in early postnatal life, and from puberty to adult life (Saez, 1994). Primarily expressed in the gonads, the receptor is also found in extragonadal organs, including the prostate (Tao et al., 1995; Reiter et al., 1995), epididymis (Lei et al., 2003), and seminal vesicles (Tao et al., 1998), although the physiological relevance is not completley elucidated.

Several gain-of-function and loss-of-function mutations of the hCG subunits and/or dimers have been developed in mice (Hutaniemi, 2000; Matzuk et al., 2003). The animals displayed a severe phenotype regarding the gonads, but without a direct influence on the vascular system suggesting that gonadotropin may play an important role in the "fine-tuning" of angiogenesis. Through the regulation of ubiquitous expressed angiogenic factors the gonadotropin mediates both survival and progesterone synthesis in the corpus luteum. HCG/LHR knockout experiments were carried out in mice with two different approaches (Lei et al., 2001; Zhang et al., 2001). Using both methods of receptor inactivation no impact on mortality during embryogenesis or postnatal life until day 60 was observed. The infertile animal had normal genitalia, but the levels of estrogen, progesterone, and testosterone were dramatically decreased. Thus, it appeared that the development and functioning of the vascular system was not disrupted.

\subsubsection{Ovarian angiogenesis}


In the ovary, the vascular supply is formed on a cyclic basis. During the menstrual cycle, small primordial follicles do not possess their own capillary network, but are dependent on proximal stromal vessels (Geva and Jaffe, 2000). Primary follicles begin to develop one or two arterioles. Soon after the antrum appear, the follicles acquire a vascular wreath in the theca which, when fully established, consists of two concentric networks of vessels in the theca interna and externa, respectively. The establishment of the vascular network in the follicle coincides with a period of rapid growth and differentiation. Shortly before ovulation, the capillaries develop a fenestrated phenotype, sprout rapidly, and invade the inner granulosa cell layer.

At the time of ovulation, the follicule collapses and is rebuilt such that each granulosa cell comes in contact with the vascular bed. After ovulation, the remaining cells of the ruptured follicle form a transient endocrine structure, the corpus luteum, which is critical for the successful maintenance of early pregnancy.

In the early luteal phase, the corpus luteum doubles in size and cell number every 60-70 hr (Reynolds et al., 1994) with 50-85\% of the cell proliferation occuring in the microvascular compartment (Reynolds et al., 1994, 2000; Christenson and Stouffer, 1996; Redmer et al., 2001). As a result, in the mature corpus luteum, pericytes and microvascular endothelial cells comprise $40-70 \%$ of the total cell population (Reynolds et al., 2000; Redmer et al., 2001). It is believed that blood vessel formation is critical not only for oxygen and nutrient supply of the growing cell mass but also for the transport of hormonal precursors and progesterone from the lutein cells (Redmer and Reynolds, 1996). By the mid-luteal phase, endothelial cell proliferation continues at a lower rate with no significant change in endothelial cell number between the late and the rescued corpus luteum (Wulff et al., 2001).

In a cycle where pregnancy has not occurred, follicles undergo atresia in the late luteal phase, starting with regression of the vascular system and ending with tissue 
remodelling in terms of connective tissue growth (Greenwald, 1989). In a fertile cycle, the corpus luteum persists in the presence of logarithmically increasing concentrations of hCG and further improves its vascular system. There is a strong evidence that angiogenesis in corpus luteum is mediated by the interplay between hCG and VEGF.

\section{VEGF and ovarian angiogenesis}

Recently, Ferrara and co-workers (1998) demonstrated the essential role of VEGF for corpus luteum angiogenesis. VEGF protein expression was increased in the theca cell layer, when the microvascular comparment was vigorously proliferating. Other studies correlated VEGF expression with extent of angiogenesis and maturation of growing follicles (Ravindranath et al., 1992; Otani et al., 1999). Dickson and colleagues (2001) verifed these data in marmoset monkeys, describing high VEGF expression in the early and mid-luteal phase and its downregulation after initiation of luteolysis. Both studies are in agreement with primary findings in a bovine model (Goede et al., 1998).

Functional proof of this concept was presented in marmoset monkeys which were treated - after hormonally induced ovulation - with VEGF neutralizing antibodies (Fraser et al., 2000). The antibody treated animals showed a virtually complete suppression of corpus luteum angiogenesis, whereas the hormone producing cells remained largely unaltered. Hazzard and colleagues, (2002) verified these data in rhesus monkeys, by demonstrating that the application of sFlt-1 captured VEGF protein and subsequently impaired ovulation.

The functional coherence of VEGF expression and corpus luteum progression were first exhibited in rhesus monkey and in mice, respectively (Zimmermann et al., 2001a; Zimmermann et al., 2001b). In macaques, Fraser and colleagues (2005) showed by administration of a VEGF trap in the early or mid-luteal phase that VEGF is critical for 
both the development and maintenance of luteal function. There is strong evidence, that the VEGF effect in corpus luteum is mediated by VEGFR-2. After induction of ovulation with pregnant mare`s serum gonadotropin (PMSG)/hCG, mice were subjected to VEGFR-2 antibodies prior to and during hormone induction. This treatment resulted in a nearly complete suppression of ovarian weight. Necrosis in the centre of the corpus luteum of treated animals was detected in parallel with the absence of vascular structures.

Direct evidence of hCG influence on VEGF expression were demonstrated by Laitinen and colleagues (1997). They showed increased levels of VEGF mRNA in vitro after treatment of human granulosa-luteal cells with hCG. Furthermore, hCG was shown to induce VEGF protein expression in follicles from women undergoing IVF (Lee et al., 1997). HCG seemed also to rescue the corpus luteum and induced endothelial cell and pericyte proliferation or distribution in humans (Wulff et al., 2001). In parallel, the developing corpus luteum exhibited an intense immunostaining for VEGF, which declined in the late corpus luteum. Christenson and Stouffer (1997) demonstrated that the synthesis and secretion of VEGF protein by granulosa cells of rhesus monkeys increased eight-fold in response to hCG. Similar data were presented by Hazzard and co-workers (1999) in macaques revealing a six-fold increase of VEGF protein in follicular fluids after hCG treatment. This mechanism seems to be of general relevance, since CG increased the low basal VEGF expression in pig corpus lutea (Barboni et al., 2000).

HCG not only influenced VEGF as a primary angiogenic factor during corpus luteum development, but also modulated the angiopoietin family (Wulff et al., 2000). Ang-1, which is required for stabilisation of newly formed vessels, was expressed at low levels 
in most human luteal cells. It was upregulated in the early luteal phase paralleld to increased expression of the receptor Tie-2 on endothelial cells of the corpus luteum. During the mid-luteal phase, the time period when the capillary network is established, Ang-1 and Tie-2 mRNA were significantly decreased. On the other hand, Ang-2, as a factor that mediates destabilization of blood vessels, was highly expressed in individual cells throughout the corpus luteum. It was proposed that during the early luteal phase areas of high Ang-2 expression correspond to regions of ongoing angiogenesis. Following hCG injections, mRNA levels for Ang-2 increased. Tie-2 expression followed the upregulation of its ligands, Ang-1 and Ang-2. The study demonstrated that angiopoietins, as well as VEGF, played an important role in the regulation of vascular development during luteal rescue in humans and both growth factor groups were regulated by hCG.

\section{Male reproductive system and gonadotropins}

The testicular vasculature is unique in several ways. The unfenestrated endothelial cells of the testis showed at least 10 -fold higher proliferation rate when compared to most other organs (Collin and Bergh, 1996). This rate could be further increased by hCG stimulation of Leydig cells (Collin and Bergh, 1996). In addition, hCG influenced testiclar blood flow (Setchell et al.,1981; Geesaman et al., et al., 1992), and increased vascular permeabilty in rat testis (Bergh et al., 1993).

Similar to the ovary (Shweiki et al., 1993; Ergun et al., 1997), both VEGFR-1 and -2 expression were shown in testicular blood vessels of humans and rodents (Ergun et al., 1997). After subcutaneous injection of hCG, VEGF as well as VEGFR-1 and -2 mRNA were upregulated in rat testis (Rudolfsson et al., 2004). HCG also induced VEGF expression in a transformed mouse Leydig cell line (MA-10 cells) (Schwarzenbach et al., 2004). 
Additionally, expression of the angiopoietin family was regulated by hCG. Ang-2 was localized in the luminal borders of intratesticular blood vessels in nonstimulated rat testis (Haggstrom et al., 2003). Stimulation with hCG caused increased Ang-2 staining in the entire endothelial layer. Similar to Tie-2, a prominent Ang-1 protein expression was observed at the luminal border of endothelial cells in all types of intratesticular blood vessels. Both molecules were largely unaffected by hCG treatment.

High vascular Ang-1 expression is apparently involved in maintaining of the highly restrictive endothelial cell barrier in the central nervous system (Haggstrom et al., 2003). A comparably high Ang-1/Ang-2 balance could serve a similar role in the unstimulated rat testis. This could also explain why testicular microvessels that are normally exposed to VEGF do not show the morphological fenestrated phenotype observed in other vessels after VEGF exposure (Huminiecki et al., 2001; Bates et al., 2002). By inducing Ang-2 expression hCG altered the microvascular Ang balance and destabilize endothelial cell layer (Bergh et al., 1996). In line with this, injection of VEGF into animal testis increased endothelial cell proliferation, but in contrast to most other tissues, in which VEGF cause a major acute increase in vascular permeability (Dvorak et al., 1991; Roberts and Pallade, 1995), permeability was only moderatly increased in the testis (Haggtrom et al., 2003). Treatment with a specific VEGFR-2 antibody blocked the hCG-induced endothelial cell proliferation, but did not affect the hCG-induced permeability of the blood vessels (Rudolfsson et al., 2004). Taken together, the regulation of the testicular microvasculature show some similarities with the ovarian vasculature, in which VEGF, Ang-1 and -2 were regulated by hCG.

\subsection{2 blood vessel formation in the uterus}

\section{General processes}


A crucial stage in pregnancy is the implantation of the embryo into the endometrium.

Once fertilization occurs, the blastocyte is implanted in the interstitium of the upper part of the zona functionalis, the zona impacta. The blood vessels of the following endometrial layers, the zona spongiosa and compacta, start to enlarge, building a capillary network adjacent to the uterus epithelium, providing maximum blood supply to the upper parts of the endometrium. Subsequently, the endometrium becomes decidua.

One of the key vascular changes during human pregnancy is remodelling of the decidual microvasculation by trophoblast or its secretory products (Jaffe, 1998). A growing body of evidence suggests a central role for hCG in the adaptation of uterine vasculature to the rising needs of the fetus. It occurs through vasodilatation, increased permeability of existing vessel and the development of new vessels.

Previous studies, using in situ hybridisation and immunohistochemistry, revealed that the hCG/LHR were abundantly expressed on uterine endothelial cells $\underline{\text { in vivo }}$ (Lei et al., 1992; Toth et al., 1994), and the receptor expression was increased in the luteal phase. Some authors postulated that the hCG-hCG/LHR complex plays an important role in uterine adaptation during implantation and placentation (Reshef et al., 1990; Licht et al., 2003a). Our own $\underline{\text { in }}$ vitro studies have demonstrated, that hCG has an angiogenic effect on uterine endothelial cells (increased migration and capillary formation). Increased neovascularisation was also seen ex ovo (Zygmunt et al., 2002). Furthermore, hCGsecreting tumors (e.g. choriocarcinoma, endometrium, and ovarian carcinoma) promoted in vitro neovascularization.

HCG might also regulate endothelial / decidual vascularisation via VEGF secretion. Intrauterine VEGF concentrations are regulated in a time dependent manner. Levels of VEGF protein reached maximum concentration in the human endometrium during the 
secretory phase, a time when endometrial endothelial cell proliferation is maximal and decidualization takes place (Ferenczy et al., 1979; Shifren et al., 1996). In humans, VEGF mRNA and protein were expressed in glandular epithelial cells, with more diffuse localization in stromal cells throughout the cycle (Shifren et al., 1996) and maternal macrophages were localized the first trimester of pregnancy (Cooper et al., 1995). Furthermore, it was established that hCG induced VEGF expression in macrophages, thereby possibly regulating macrophage functioning in the uterus (Zhang et al., 2003; Zygmunt et al., unpublished observations). After establishing an elegant intrauterine microdialysis system, Licht and colleagues, (2001) monitored human female uterine physiology after hCG treatment. He showed that hCG application via the microdialysis device during the secretory phase modulated VEGF expression (Licht, 2006).

There is also evidence that hCG has strong vasodilatory effects on uterine arteries in pregnant and non pregnant rats and humans, due to the fact that the spiral and radial uterine artery express high levels of hCG/LH receptors (Hermsteiner et al., 1999). Toth and co-workers (1994) localized LH/hCGR mRNA and protein in endothelial and smooth muscle cells human uterus arteries. Incubation of the uterine arteries with hCG resulted in a dose-dependent upregulation of vascular tonus regulating factors like cyclooxygenase-1 and -2. After treatment with high concentrations of hCG for ovulation induction in woman, the resistance of uterine arteries, but not common carotid arteries, decreased significantly.

\subsubsection{Vessel formation in the placenta}

\section{General processes}


In humans, placental vasculogenesis is evident by approximately 21 days post conception (pc) (Demir et al., 1989). Cords of hemangioblasts become visible in the secondary villi establishing tertiary villi until approximately day 28 pc. Vasculogenesis continues to appear sporadically through 14 weeks pc. The vascular volume of each villi increases during the first trimester via branching angiogenesis (te Velde et al., 1997). In parallel, the distance between the intervillous space and the villous capillary compartment decreases (Jauniaux et al., 1991). During the second trimester, the placenta exhibits dramatic growth accompanied by a substantial increase in vascular volume. Most of the increase seems to be due to non-branching angiogenesis in terms of endothelial cell proliferation (Mayhew, 2002).

Since the human placenta is unique, there are no functional studies on the regulation of blood vessel formation during placentation. The origin of the endothelial precursor cells remains unknown. It was prosposed that the trophoblast and early appearing macrophages (Hofbauer cells) in the villous core of the secondary villi express VEGF and attract hemangioblasts derived from the embryo or extraembryonic tissues like the yolk sac. In contrast, several studies suggested that precursor cells also arise from the placenta itself (Ottersbach et al., 2005; Mikkola et al., 2005). Hematopoietic cells in the placenta seemed to have different characteristics than cells in the yolk sac (Challier et al., 2005). Several studies identified precursor cells and their derivates before adequate cells were visualised in the embryo (Melchers et al., 1979; Alvarez-Silva et al., 2003).

\section{hCG mediated mechanisms}

There is some evidence that hCG also has an impact on placental vascularization.

HCG/LHR is highly expressed in the syncytiotrophoblast and to a lesser extent in the cytotrophoblast in the first and second trimester whereas no staining is apparent by at 
the end of gestation (Reshef et al., 1990). Despite the findings of Reshef and coworkers, Rao and colleagues detected hCG/LH receptor on placental endothelial cells (personnel communications). Furthermore, the receptor could be detected on cells extracted from umbilical cord blood which displayed a hematopoietic/endothelial precursor phenotype (Baal et al., 2004).

Comparable with mechanisms in corpus luteum and uterus the VEGF and angiopoietin modules seemed to play a pivotal role in placental vascularisation as well. It was shown that homozygous VEGF gene knockouts were lethal between day 9.5 and 10.5 of mice embryogenesis exhibiting severe cardiovascular defects like a disturbed or delayed development of the heart, the major vessels, and extraembryonic vasculature in the yolk sac and the placenta. Heterozygous VEGF-gene knockouts showed similar effects in fetal and placental blood vessel formation resulting in fetal death by about day 11 of gestation (Carmeliet et al., 1996; Ferrara et al., 1996). Thus, not only fetal and placental vascular formation are dependent on VEGF expression, but also threshold levels of VEGF must be achieved for normal blood vessel formation to occur.

VEGF was expressed in the villous trophoblast, the decidua and macrophages of both fetal and maternal origin (Sharkey et al., 1993; Ahmed et al., 1995; Vourela et al., 1997). During the first trimester, VEGF protein expression was localized to the cytotrophoblast in parallel with VEGFR-1 expression, suggesting an impact on trophoblast growth and differentiation in the first phase of gestation (Charnock-Jones et al., 1994; Ahmed et al., 1995). At term VEGF and Flt-1 expression had changed to a more intense staining in the Hofbauer cells. VEGFR-2 was localized on endothelial cells and the cytotrophoblast from the first to the third trimester at moderate levels. However, hemangioblasts showed the strongest expression of VEGFR-2 (Vuckovic et al., 1996, Demir et al., 2004). The angiopoietin system is also involved in placental 
formation. Ang-1 is highly expressed in the syncytiotrophoblast, whereas its receptor Tie-2, was located in the cytotrophoblast in humans and monkeys (Dunk et al., 2000; Zhang et al., 2001; Geva et al., 2002, Rowe et al., 2003). However, there is no experimental evidence for a role of hCG in the regulation of the angiopoietin family in the placenta.

We assume that the trophoblast have a direct influence on placental vascularization, first, by secreting angiogenic factors, and secondly, by direct cell-cell interactions. The influence of hCG on the expression of the VEGF system might be of special importance (Zygmunt et al., unpublished data).

The trophoblast determines not only the regulation of fetal blood vessels, but also of maternal tissues during placentation. As summarized above, the high vascular supply during pregnancy is first met by intense angiogenic processes in the maternal endometrium by hCG. Secondly, the increased vascularisation of the uterus results essentially from the invasive behaviour of cytotrophoblastic cells that invade and colonize the endometrial spiral arteries allowing a loss of their elasticity (Fisher et al., 2000). Our laboratory showed that migration of a cytotrophoblastic cell line was dosedependently induced by hCG and that the collagenase activity, as an attribute of a migratory phenotype, was upregulated stimulated cells (Zygmunt et al., 1998). There is evidence that hCG meditated this effect by influencing the availiability of insulin-like Growth Factor-II (IGF-II), an essential factor for migration of placental and tumor cells (Zygmunt et al., 2005). We assumed that hCG stimulated trophoblast migration by increasing IGF-II binding to the plasma membrane and subsequently by increasing the IGF-II effect probably mediated via IGF-II receptor. Cytotrophoblasts are specialized epithelial cells that develop endothelial-like characteristics such as the expression of Ang-2 (Zhou et al., 2003). This transformation allows cytotrophoblasts to replace the 
maternal cells that line uterine vessels, thereby diverting maternal blood to the placenta. It was shown that in human cytotrophoblasts isolated from legal abortion tissues that hCG upregulated VEGF secretion in a dose-dependent manner (Islami et al., 2003). Finally, maternal blood flow in the intervillous space increased 20-fold during pregnancy due to vasomotor changes of the distal intramyometrial portions of uteroplacental ateries and the transformation and dilatation of decidual segments. The increased blood flow might be induced by hCG.

\subsection{The impact of LH on blood vessel and oviduct physiology}

LH is the pituitary homolog of placental hCG. Both hormones bind to the same receptor, LH with a lesser affinity. After the initial inductive effect of FSH on LHR expression in the small and medium follicles, LH enhances the subsequent stages of follicular development and steroidogenesis in granulosa and luteal cells (Richards and Hedin, 1988). The midcycle surge of LH triggers events within the primate periovulatory follicle that culminate in follicle rupture and luteinization of the follicle wall. This process includes the shift from primarily estrogen to primarily progresterone production, vascularization of the granulosa cell layer, and expression of matrix metalloproteinases and their inhibitors. Just before follicle rupture, the ovulatory LH surge also stimulates the production of prostaglandins.

These common properties were convincingly extended in a chorioallantoic assay (Redmer et al., 1988). LH exhibited general angiogenic properties by inducing endothelial mitogenesis and migration. This was verified by the stimulation of bovine granulosa cells with LH leading to a dose-depended upregulation of VEGF protein expression. Simultaneous application of IGF-I had synergistic effects (Schams et al., 
2001). However, the angiogenic effects of LH in the reproductive system were less pronounced compared with the influence of hCG despite binding to the same receptor. Immature female rats were treated with hCG, LH, FSH. All three gonadotropins were effective in triggering ovulation, but LH mediated a significantly lower vascular permeability and VEGF mRNA expression in ovarian cells (Gomez et al., 2004).

It seemed that LH effects are more generally focused on regulation of ovarial and tube physiology. There is no data on the direct angiogenic action of LH available. Thus, LH was able to increase ovarian blood flow in several species (Wurtman et al., 1964; Janson et al., 1975). Likewise, LH regulated aterial blood flow in the uterus during the preovulatory LH surge in both cows and rats (Ford et al., 1981; Varga et al., 1985). Furthermore, there is evidence that $\mathrm{LH}$ also regulates contraction of the oviduct via VEGF expression. Immunostaining of oviduct tissues from fertile woman undergoing tubal sterilization or hysterectomy detected VEGF protein in the oviduct luminal epithelium, smooth muscle cells, and blood vessels within the oviduct. VEGF mRNA expression was the highest during the periovulatory stage and was significantly correlated with LH concentration (Lam et al., 2003).

In bovine oviductal epithelial cells LH increased VEGF mRNA expression and both its receptors whereas VEGF mediated downregulation of the oviductual VEGF system. This downregulation was further intensified in the presence of LH (Wijayagunawardane et al., 2005). The periovulatory stage was associated with the highest contraction acitivity of the oviduct and the LH-VEGF interrelation might regulate oviductual contraction to assure an optimal transport of the oocyte through the oviduct by regulation contraction. 
In the male gonads, LH plays a role in both normal and abnormal reproductive function by modulating testicular Leydig cell differentiation and steroidogenesis. Testosterone secreted by Leydig cells, in turn, promotes male sexual differentiation pubertal androgenization, and fertility. Naturally occuring mutations of the hCG/LH receptor have been associated with disrupted reproductive function (Themmen and Huhtaniemi, 2000). No studies have investigated the influence of LH on vascular biology in the testis.

\subsection{FSH and blood vessel formation in the female reproductive system}

In women, FSH has a critical role during development and growth of ovarian follicles, including granulosa cell function, and production of estrogens from androgen substrates. The hormone appears in many different molecular forms, which may reflect different reactivitites. An overall change in FSH isoform pattern resulting in a more basic composition has been observed in the middle of the menstruation cycle during puberty (Phillips et al., 1994). In adult women, a more acidic form of FSH appears after menopause, exhibiting a longer half-life which may contribute to the observed increase in serum FSH concentration (Wide, 1989; Wide and Hobson, 1983).

It is known that FSH receptors are present in the granulosa cells of the growing follicle at the preantral and Graafian stage (Peters et al., 1979). Furthermore, primary, two layer, and multi- laminar follicles have been shown to express FSHR mRNA, indicating that FSH may have a physiological role in preantral follicular development (Oktay et al., 1997). The FSHR has also been localized on granulosa and luteal cells of several other species (O`Shaugnessy et al., 1996). 
In rhesus monkeys it was demonstrated that FSH also has an impact on blood vessel formation in corpus luteum. Granulosa cells before an ovulatory surge of FSH produced low levels of VEGF. Recombinant FSH, either administered in vivo as an ovulatory bolus or added to $\underline{\text { in vitro }}$ cultures in high doses stimulated VEGF production in granulosa cells derived from large antral follicles (Christenson and Stoufer, 1997). The direct dependence of hCG and VEGF effects were proven by analysing corpus luteum from women undergoing $\underline{\text { in vitro }}$ fertilisation (Laitinen et al., 1997). After treatment of human granulosa-luteal cells with FSH, increased levels of VEGF mRNA could be observed.

In the male gonads FSH plays a major role in Sertoli cell proliferation in maturing testis, which in turn, influences Leydig cell function (Sharpe, 1993). No information of the role of FSH in the regulation of testicular blood vessels is presently available.

\subsection{Impact of TSH on angiogenesis}

TSH possesses intrinsic gonadotropic activity as the other gonadotropins in males and females e.g. by stimulating progesterone secretion during initial luteinization of rat granulosa cells in vitro (Csaba et al., 1980; Shahin et al., 1980; Grasso et al., 1985). However, it has a greater impact on thyroid regulation by promoting thyroid follicle development and hormone secretion, thereby modulating an organ which is also highly vascularized such as the female reproductive organs. Pathological conditions such as Graves` disease, thyroid enlargement and hyperfunction are accompanied by an even increased blood vessel system. There is strong evidence that TSH regulate tissuespecific angiogenesis in physiological conditions and pathological situations. Thus, increased levels of VEGF and TSH protein correlated with each other and were related 
to the extension of the vascular area in the thyroid parenchyma in Grave`s disease, Hashimoto`s thyroiditis, and subacute thyroditis (Iitaka et al., 1998). In goiter biopsies, taken from Graves's patients, VEGF and both its receptors were upregulated (Biglietto et la., 1997). Studies with a rat model of thyroid goitrogenesis revealed an increased mRNA and protein expression of VEGF, VEGFR-1 and -2 after TSH treatment, in parallel with thyroid capillary proliferation. The conditioned medium of TSH-stimulated thyrocytes mediated mitogenic activity of HUVECs. This approach verified the work of Sato and co-workers (1995), who showed that in human thyroid follicles from patients with Grave`s disease TSH treatment upregulated VEGF expression in vitro and in a model in vivo. Furthermore, TSH induced VEGF mRNA and protein expression in some tumor cell lines (Soh et al., 1996; Hoffmann et al., 2004).

TSH also mediated upregulation of Tie-2 and Ang-2 mRNA in goiters from both humans and rats (Cocks et al., 2000; Ramsden et al., 2001). Apparently opposite findings displaying reduced VEGF expression after TSH treatment (Sorvillo et al., 2003), might be due to experimental settings like time point and duration of TSH application (Tuttle et al., 2002). The effects of VEGF in the thyroid are more complex than in the female reproductive system. In goiter, VEGF is upregulated throughout the thyroid follicular and endothelial cells. It was shown that VEGF inhibited both TSHdependent DNA synthesis and iodide uptake in vitro (Wang et al., 1998). Thus, it was suggested that VEGF provides a feedback system to limit thyrocyte proliferation, and to maintain a balance between thyrocyte mass and the expanding capillary network.

In conclusion, TSH can act as a organ-specific angiogenic factor as well, but the interrelationship between TSH and one of ubiquitous factor seems to be much more complex.

\subsection{Vascular development and pregnancy-related disorders}


Angiogenesis is required for early implantation and placentation to be successful and it is likely that human gestation is dependent upon at least three temporally different vascular processes: (1) adequate uterine angiogenesis at the time of implantation, (2) development and expansion of the placental - villous - vasculature soon after implantation and (3) remodelling of the maternal uterine circulation near the maternalfetal interface (Torry 2004). Consequently, it is possible that disruption of these early vascular events may contribute to the pathology of conditions like preeclampsia or growth retardation of the fetus (Khong et al., 1986; Starzyk et al., 1999). In contrast, increased vascular formation is also observed in the female reproductive tract and is associated with endometriosis and ovarian hyperstimulation syndrome. A short description of these disturbed vascular conditions, the review will delineate organ- and situation-specific sensitive regulation of vascular biology in the human organism.

\subsection{Preeclampsia}

Preeclampsia and intrauterine growth restriction both display impaired vascular function in the fetal and maternal compartments. In detail, preeclampsia is a multifactorial disease process that most likely involves immune components, inflammation, genetics, cytokines or vascular factors, and contributes significantly to maternal and perinatal morbidity and mortality (Torry et al., 2004). Its aetiology is still unclear, but its manifestation in mid-gestation is regarded as a disorder of early placentation and culminates in generalized maternal endothelial cell dysfunction that is characteric for preeclampsia (Taylor et al., 1998; Roberts, 1998).

In the fetal compartment, insufficient trophoblast invasion is thought to result in more tortuous arteries with smaller lumens and thicker walls compared with normal placental 
bed arteries (Starzyk et al., 1997). Others have shown that preeclampsia is associated with smaller capillary lengths, but with larger diameters than in control placentas (Burton et al., 1996). These structural changes probably contribute to reduced placental perfusion and placental hypoxia (Kingdom and Kaufmann, 1999). It should be noted however, that more recent studies have found remarkable little differences in placental vasculature architecture in preeclampsia as compared with normal pregnancies (Mayhew, 2003). As preeclampsia is characterised by disturbed trophoblastic physiology, altered hCG concentrations are thought to reflect early placental dysfunction (Redman, 1991). Numerous studies have suggested a link between elevated maternal hCG serum levels and preeclampsia (Ashour et al., 1997; Hsu et al., 1994; 1998; Merviel et al., 2001; Barros et al., 2002; Bartha et al., 2003), whereas Huang and colleagues (1989) as well as Wenstrom and co-workers (1994) could not detect significant differences in hCG concentration in maternal blood of preeclamptic and normal pregnancies. The mechanism of serum hCG elevation is not clarified, but may be the result of an abnormal synthesis and release of hCG by the syncytiothrophoblast. Furthermore, in preeclampsia, endovascular invasion of the cytotrophoblast remains superficial and fails to undergo pseudovasculogenesis, due to severe failures of this cell compartment (Jones et al., 1980; Zhou et a., 1997). Therefore, the uterine blood vessels do not undergo adequate vascular transformation compared to normal pregnancy (Brosens et al., 1972). In addition, the constituents of the serum or plasma from preeclamptic patients were shown to cause alterations in endothelial functions as well. Many mediators such as cellular fibronectin (Lockwood et al., 1990; Taylor et al., 1991; Friedmann et al., 1994), thrombomodulin (Minatami et al., 1993; Boffa et al., 1998) and von Willebrand Factor (Calvin et al., 1988; Thorp et al., 1990) were elevated during preeclampsia and seemed to disturb vascular physiology. This was supplemented by the findings that the soluble VEGFR-1 (sVEGFR-1) was also upregulated in the serum 
(Tsatsaris et al., 2003; Helske et al., 2001), peripheral blood mononuclear cells (Vourela et al., 2003; Rajakumar et al., 2005) and urine (Roes et al., 2004) of preeclamptic patients. In addition, increased concentrations of VEGFR-1 and sVEGFR-1 were also measured in fetal serum (Staff et al., 2005). The increased systemic levels of sVEGFR-1 in patients with preeclampsia decreased to baseline 48 hours after delivery (Maynard et al., 2003). Recently, Chaiworapongsa and colleagues (2005) demonstrated that the sVEGFR-1 concentration was elevated prior to clinical diagnosis of preeclampsia and could be used as a predictive marker. Increased circultating sVEGFR-1 concentrations in preeclamptic patients were associated with decreased circulating levels of free VEGF and PlGF, leading to an anti-angiogenic state and causing endothelial dysfunction. A finding that was reported by a number of groups (Reuvekamp et al., 1999; Koga et al., 2003; Polliotti et al., 2003; Tsatsaris et al., 2003). In the contrast, also several studies exist, which described rising VEGF protein levels in the patients serum (Kupferminc et al., 1997; Shaarawy et al., 2005) or umbilical cord blood (Galazios et al., 2004).

In a recent study, uterine vein sVEGFR-1 concentrations were almost 4- to 5-fold higher than the uterine arterial concentrations, suggesting that the predominant source of maternal sVEGFR-1 was the placenta (Bdolah et al., 2004). Thus, several groups observed elevated concentration of VEGFR-1 protein in the syncytiotrophoblast from patients with preeclampsia (Helske et al., 2003; Chung et al., 2004), while VEGF protein concentrations seemed to decrease (Ahmad et al., 2004; Chung et al., 2004)

Nevertheless, a direct correlation between elevated hCG and VEGF serum concentration in the patients serum could not be established up to now (Bartha et a., 2003). In contrast to hCG, FSH and LH do not seem to be not involved in preeclamptic processes. However, an impact of TSH on preeclampsia was demonstrated. Several 
studies revealed a correlation between preeclampsia, elevated TSH concentration in maternal serum and reduced birth weight (Basbug et al., 1999; Qublan et al., 2003; Larijani et al., 2004). Other thyroid hormones, namely triidithyronine (free T3) and thyroxine (free T4) remained unchanged or showed reduced levels in the same studies. The mechanism and the effect of these observations are still to be clarified.

\subsection{Intrauterine growth restriction (IUGR)}

Intrauterine growth restriction is a significant cause of infant mortality and morbidity (Pollack and Divon, 1992). It is now clear that IUGR infants exhibit higher rates of coronary heart disease, type-2 diabetes, hypertension and stroke as adults. Therefore, fetal growth not only impacts the outcome of the perinatal period, but also impacts adult well being. While IUGR fetuses can be categorized into symmetric and asymmetric patterns of growth, the majority of cases present asymmetric patterns of growth, often associated with abnormalities in placental structure and function. This includes a decrease in villous number, diameter and surface area, as well as a decrease in arterial number, lumen size and branching (Giles et al., 1985; Macara et al., 1996; Salaria et al., 1997).

Normally, extravillous trophoblast cells migrate and invade the spiral artery vessel walls within the decidua and myometrium, but in pregnancies complicated by IUGR, this invasion is largely restricted to the decidual portion mediating failure of these arteries to become low resistance vessels (Meekins, et al., 1994; Redline and Patterson, 1995). This disturbed process is accompanied by hypoxia and an altered expression of many factors which regulate implantation and placentation such as growth factors, cell adhesion molecules, extracellular matrix proteins, hormones, and transcription factors. 
There are also strong associations between abnormal karyotype, Mendelian single gene disorders, uniparental disomies, and IUGR (Cetin et al., 2004).

Different conditions of hypoxia can be distinguished during IUGR, evaluating the compartment (fetal or maternal) which stays under the influence of reduced $\mathrm{O}_{2}$ concentrations and the onset of hypoxic conditions (Regnault, 2002). The resulting variability in pathological stages makes it difficult to clarify the aetiology of IUGR. Using an ovine model for IUGR significant changes in the expression of the VEGF- and angiopoietin-modules were observed, thereby indicating a perturbation of fetal-maternal oxygenation (Regnault et al., 2002).

Analyses of human IUGR placentas demonstrated a significantly reduced expression of VEGF and Ang-2 protein, whereas increased levels of placental-derived growth factor (PlGF) could be observed (Lyall et al., 1997; Khaliq et al., 1999; Dunk et al., 2000). PlGF belongs to the VEGF family exerting its function only by VEGFR-1 and its mRNA and protein expression is localized to the trophoblast bilayer and villous mesenchym throughout gestation. The altered balance of VEGF- and PlGF- expression impaired the vasorelaxtion of isolated placental vessels of patients with IUGR (Szukiewicz et al., 2005). It is not known how VEGFR-1 and -2 expression are regulated at various times during the development of IUGR. Nevertheless, the expression of VEGF and VEGFR-1 is not changed during early stages of IUGR suggesting that VEGF has no impact in the early stages of IUGR (Khaliq et al., 1999; Lash et al., 2001).

Although, $\beta$ hCG concentration is increased in women suffering IUGR (Bartha et al., 1997; Mikic et al., 1999), a mechanistical impact was not demonstrated so far. Thus, no significant correlation was found between the alteration of $\beta$ hCG and VEGF 
concentrations in the maternal serum of pregnancies complicated with fetal growth restriction (Bartha et al., 2003)

\subsection{Ovarian hyperstimulation syndrome (OHSS)}

OHSS is a serious iatrogenic complication of controlled ovarian hyperstimulation, arising from treatment with gonadotropin in order to induce follicular growth and maturation. The clinical picture is characterized by ovarian cystic enlargement and severe ascites and/or pleural affusion, induced by increased vascular permeability. This condition is potentially lethal (Schenker et al., 1978).

The pathology of OHSS is poorly understood, but the interrelationship of hCG and VEGF by mediating angiogenic processes seems to have a great impact on this disease (Lee et al., 1997; Agrawal et al., 1999). It was shown that hCG induced VEGF expression in a time- and dose-dependent manner in human luteinised granulosa cells $\underline{i n}$

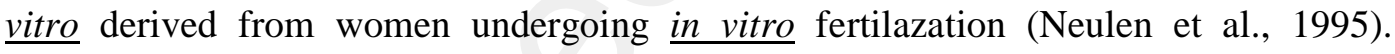
Furthermore, Wang and co-workers showed that hCG is able to upregulate VEGF expression in luteinized granulosa cells from women who developed severe OHSS, but in contrast, hCG had no effect on VEGF synthesis in control patients. In addition, VEGF concentrations in serum, peritoneal fluid, and follicular fluid of patients at risk for OHSS are positively related to the development of the syndrom. In hyperstimulated rats sFlt-1 could capture VEGF protein and the peritoneal permeability was significantly lower than in non treated rats (McElhinney et al., 2003). The hCG-induced VEGF expression is ovary-specific. Female rats stimulated with equine CG followed by injections of hCG, in order to induce hyperstimulation, upregulatd VEGF expression in the ovary. VEGF expression in lung and liver of the same animal were not affected 
(Ishikawa et al., 2003). Similar findings were demonstrated after hyperstimulation of female immature Winstar rats with hCG. Gomez and co-workers (2002) observed an increased VEGF mRNA expression and vascular permeability in the ovary, but not in mesenterium of the animal. The VEGF effects seemed to be mediated by induced VEGFR-2 expression (Gomez et al., 2003).

LH and FSH display milder effects during hyperstimulation. Although, hCG has a longer half life and a greater biological activity than LH, LH can be used in reduced concentration to induce hyperstimulation associated with a reduced VEGF expression and vascular permeability (European Recombinat LH Study Group, 2001; Gomez et al., 2004).

\subsection{Endometriosis}

Endometriosis is a common, benign, estrogen-dependent, chronic disorder associated with pelvic pain and infertility. It is characterized by the presence of uterine endometrial tissue outside of the normal location, mainly on the pelvic peritoneum, but also in the ovaries and in the rectovaginal septum. Although, no single theory can explain all cases of endometriosis, the most commonly accepted hypothesis is Sampson`s theory of retrograde menstruation, which occurs in 76-90\% of women. The much lower prevalence of endometriosis suggests that additional factors determine susceptibility to endometriosis. Thus, heritable features, environmental factors and components of the immune system contribute to endometriosis. Vessel formation represents the crucial step in the pathology of endometriosis, due to the fact that endometric lesions require neovascularization to establish, proliferate, and invade inside the peritoneal cavity. This is indicated by elevated levels of angiogenic factors such as IL-6 (Pellicer et al., 1998; Garrido et al., 2001), IL-8 (Fasciani et al., 2000), the angiopoietins (Drenkhan et al., 
2004), and VEGF (Takehara et al., 2004). In addition, macrophages exhibit a strong VEGF protein expression, followed by endothelial and subepithelial stroma cells of capsular vessels (Poteri et al., 2004). Elevated VEGF concentrations were also detected in peritoneal fluid, macrophage cell culture supernatant, and ectopic endometrium, suggesting that macrophages specific of ectopic endometrium contribute to higher VEGF concentrations in peritoneal fluid derived from endometrial patients (Nap et al., 2005).

However, it seems that angiogenesis during endometriosis is not solely driven by VEGF, but depends on cross-talk between other growth factors. Human endometrial isolates were transplanted into hormonally synchronized hamsters. Blockade with a selective VEGF inhibitor resulted in a slight reduction of microvessel density when compared to control animals. The application of an inhibitor of VEGF, platelet-derived growth factor, and fibroblast growth factor angiogenesis was significantly suppressed in the hamster model (Laschke et al., 2005).

VEGFR-1 and -2 were expressed in the endometrial glandular epithelium and stromal cells besides the endometrial blood vessels. The expression of both the receptors was significantly elevated in ectopic endometrium of patients suffering endometriosis in comparison with ovarian endometrial cysts (Wang et al., 2005).

In parallel, gonadotropins seem to have an impact on endometriosis as well. In women with endometriosis higher serum and pertoneal fluid levels of LH were observed in comparison with the control group (Chew et al., 1990, Illera at al, 2001). Whereas in the healthy control group, menstrual cycle dependent LH concentration in peritoneal fluid and serum could be detected, this pattern was absent in endometriosis patients. Furthermore, in subfertile woman with endometriosis a disturbed LH surge was reported (Cahill and Hull, 2000). In line with this, abnormal LH and/or hCG/LHR have been 
linked with endometriosis and associated infertility (Cheesman et al., 1982; Chew et al., 1990. Thus, LH seems to be correlated more with endometriosis associated infertiliy than with angiogenesis.

In contrast to $\mathrm{LH}$, the FSH concentration in the serum of endometriosis patients did not differ im comparison with the control group (Chew et al., 1990). Also, TSH is indirectly involved in endometrial pathology. A higher risk to develop endometriosis was reported in patients with associated thyroid autoimmunity (Poppe et al., 2002). Finally, hCG has been tested for impairing the painful endometrial symptoms (Huber et al., 2004). In conclusion there is no established link between the gonadotropins and endometrial angiogenesis.

\section{Conclusion}

The gonadotropins possess a central role in the physiology and pathology of the female reproductive system. They regulate organ metabolism by influencing hormone levels. It was shown that the gonadotropins, and especially hCG modulate primary angiogenic factors such as the VEGF and angiopoietins. The first evidence for the angiogenic properties of hCG arose in the eighties showing the therapeutical impact of hCG on coronary disease and diabetic syndrome (Mian et al., 1981; Bondarenko et al., 1984).

The molecular mechanisms of the gonadotropins in the regulation of angiogenic factors expression are not known. Thus, the analysis of the respective signal transduction pathways seemed to be a rewarding target for further studies. 


\section{References}

Abbas, M.M., Evans, J.J., Sykes, P.H., Benny, P.S., 2004. Modulation of vascular endothelial growth factor and thymidine phosphorylase in normal human endometrial stromal cells. Fertil. Steril. 82, 1048-1053.

Abdallah, M.A., Lei, Z.M., Li, X., Greenwold, N., Nakajima, S.T., Jauniaux, E., Rao. Ch.V., 2004. Human fetal nongonadal tissues contain human chorionic gonadotropin/luteinizing hormone receptors. J. Clin. Endocrinol. Metab. 89, 952956.

Adair, T.H., Gay, W.J., Montani, J.P., 1990. Growth regulation of the vascular system: evidence for a metabolic hypothesis. Am. J. Physiol. 259, R393-404.

Agrawal, R., Tan, S.L., Wild, S., Sladkevicius, P., Engmann, L., Payne, N., Bekir, J., Campbell, S., Conway, G., Jacobs, H., 1999. Serum vascular endothelial growth factor concentrations in in vitro fertilization cycles predict the risk of ovarian hyperstimulation syndrome. Fertil. Steril. 71, 287-293.

Ahmad, S., Ahmed, A., 2004. Elevated placental soluble vascular endothelial growth factor receptor-1 inhibits angiogenesis in preeclampsia. Circ. Res. 29, 884-891.

Ahmed, A., Li, X.F., Dunk, C., Whittl, M.J., Rushton, D.I., Rollason, T., 1995. Colocalisation of vascular endothelial growth factor and its Flt-1 receptor in human placenta. Growth Factors 12, 235-243.

Alvarez-Silva, M., Belo-Diabangouaya, P., Salaun, J., Dieterlen-Lievre, F., 2003. Mouse placenta is a major hematopoietic organ. Development 130, 5437-5444.

Asahara, T., Murohara, T., Sullivan, A., Silver, M., Witzenbichler, B., Schatteman, G., Isner, J.M., 1997. Isolation of putative progenitor endothelial cells for angiogenesis. Science 275, 964-967.

Ashour, A.M., Lieberman, E.S., Haug, L.E., Repke, J.T., 1997. The value of elevated second-trimester beta-human chorionic gonadotropin in predicting development of preeclampsia. Am. J. Obstet. Gynecol. 176, 438-442.

Baal, N., Reisinger, K., Jahr, H., Bohle, R.M., Liang, O., Munstedt, K., Rao, C.V., Preissner, K.T, Zygmunt, M.T., 2004. Expression of transcription factor Oct-4 and other embryonic genes in CD133 positive cells from human umbilical cord blood. Thromb. Haemost. 92, 767-775.

Barboni, B., Turriani, M., Galeati, G., Spinaci, M., Bacci, M.L., Forni, M., Mattioli, M., 2000. Vascular endothelial growth factor production in growing pig antral follicles. Biol. Reprod. 63, 858-864. 
Bartha, J.L., Comino-Delgado, R., Arrabal, J., Escobar, M.A., 1997. Third-trimester maternal serum beta-HCG level and umbilical blood flow in fetal growth retardation. Int. J. Gynaecol .Obstet. 57, 27-31.

Bartha, J.L., Romero-Carmona, R., Escobar-Llompart, M., Paloma-Castro, O., CominoDelgado, R., 2003. Human chorionic gonadotropin and vascular endothelial growth factor in normal and complicated pregnancies. Obstet. Gynecol. 102, 995-999.

Basbug, M., Aygen, E., Tayyar, M., Tutus, A., Kaya, E., Oktem, O., 1999. Correlation between maternal thyroid function tests and endothelin in preeclampsia-eclampsia. Obstet. Gynecol. 94, 551-555.

Bates, D.O., Hillman, N.J., Williams, B., Neal, C.R., Pocock, T.M., 2002. Regulation of microvascular permeability by vascular endothelial growth factors. J. Anat. 200, 581597.

Bdolah, Y., Sukhatme, V.P., Karumanchi, S.A., 2004. Angiogenic imbalance in the pathophysiology of preeclampsia: newer insights. Semin. Nephrol. 24, 548-556.

Bergh, A., Damber, J.E., van Rooijen, N., 1993. The human chorionic gonadotrophininduced inflammation-like response is enhanced in macrophage-depleted rat testes. J. Endocrinol. 136, 415-420.

Bergh, A., Damber, J.E., Hjertkvist, M., 1996. Human chorionic gonadotrophin-induced testicular inflammation may be related to increased sensitivity to interleukin-1. Int. J. Androl. 19, 229-236.

Biglietto, G., Romano, A., Manzo, G., Chiappetta, G., Paletti, I., Califano, D., Galati, M.G., Mauriello, V., Bruni, P., Lago, C.T., Fusco, A., Persico, M.G., 1997. Upregulation of the angiogenic factors PlGF, VEGF and their receptors (Flt-1, Flk$1 / \mathrm{KDR}$ ) by TSH in cultured thyrocytes and in the thyroid gland of thiouracil-fed rats suggest a TSH-dependent paracrine mechanism for goiter hypervascularization. Oncogene 15, 2687-2698.

Bockaert, J., Pin, J.P., 1999. Molecular tinkering of G protein-coupled receptors: an evolutionary success. EMBO J. 18, 1723-1729.

Boffa, M.C., Valsecchi, L., Fausto, A., Gozin, D., Vigano D'Angelo, S., Safa, O., Castiglioni, M.T., Amiral, J., D'Angelo, A., 1998. Predictive value of plasma thrombomodulin in preeclampsia and gestational hypertension. Thromb. Haemost. 79, 1092-1095. 
Bondarenko, I.P., 1984. Chorionic gonadotropin in the treatment of chronic circulatory failure in ischemic heart disease patients. Vrach. Delo. 7, 75-78.

Brosens, I.A., Robertson, W.B., Dixon, H.G., 1972. The role of the spiral arteries in the pathogenesis of preeclampsia. Obstet. Gynecol. Annu. 1, 177-191.

Burton, G.J., Reshetnikova, O.S., Milovanov, A.P., Teleshova, O.V., 1996. Stereological evaluation of vascular adaptations in human placental villi to differing forms of hypoxic stress. Placenta 17, 49-55.

Cahill, D.J., Hull, M.G., 2000. Pituitary-ovarian dysfunction and endometriosis. Hum. Reprod. Update. 6, 56-66.

Calvin, S., Corrigan, J., Weinstein, L., Jeter, M., 1988. Factor VIII: von Willebrand factor patterns in the plasma of patients with pre-eclampsia. Am. J. Perinatol. 5, 2932.

Carmeliet, P., Ferreira, V., Breier, G., Pollefeyt, S., Kieckens, L., et al., 1996. Abnormal blood vessel development and lethality in embryos lacking a single VEGF allele. Nature 380, 435-439.

Carmeliet, P., Jain, R.K., 2000. Angiogenesis in cancer and other diseases. Nature 407, 249-257.

Cetin, I., Foidart, J.M., Miozzo, M., Raun, T., Jansson, T., Tsatsaris, V., Reik, W., Cross, J., Hauguel-de-Mouzon, S., Illsley, N., Kingdom, J., Huppertz, B., 2004. Fetal growth restriction: a workshop report. Placenta 25, 753-757.

Chaiworapongsa T, Romero R, Kim YM, Kim GJ, Kim MR, et al., 2005. Plasma soluble vascular endothelial growth factor receptor-1 concentration is elevated prior to the clinical diagnosis of pre-eclampsia. J. Matern. Fetal. Neonatal. Med. 17, 3-18.

Challier, J.C., Galtier, M., Cortez, A., Bintein,T., Rabreau, M., Uzan, S., 2005. Immunocytological evidence for hematopoiesis in the early human placenta. Placenta 26, 282-288.

Charnock-Jones, D.S., Sharkey, A.M., Boocock, C.A., Ahmed,A., Plevin, R., Ferrara, N., Smith S.K., 1994. Vascular endothelial growth factor receptor localization and activation in human trophoblast and choriocarcinoma cells. Biol. Reprod. 51, 524530.

Catt, K.J., Dufau, M.L., Tsuruhara, T., 1973. Absence of intrinsic biological activity in LH and hCG subunits. J. Clin. Endocrinol. Metab. 36, 73-80.

Cheesman, K.L., Ben-Nun, Chatterton, R.T. Jr., Cohen, M.R., 1982. Relationship of luteinizing hormone, pregnanediol-3-glucuronide, and estriol-16-glucuronide in urine of infertile women with endometriosis. Fertil. Steril. 38, 542-548.

Chew, P.C., Peh, K.L., Loganath, A., Gunasegaram, R., Ratnam, S.S., 1990. Elevated peritoneal fluid luteinizing hormone and prolactin concentrations in infertile women with endometriosis. Int J Gynaecol Obstet. 33, 35-39. 
Christenson, L.K., Stouffer, R.L., 1996. Proliferation of microvascular endothelial cells in the primate corpus luteum during the menstrual cycle and simulated early pregnancy. Endocrinology 137, 367-374.

Christenson, L.K., Stouffer, R.L., 1997. Follicle-stimulating hormone and luteinizing hormone/chorionic gonadotropin stimulation of vascular endothelial growth factor production by macaque granulosa cells from pre- and periovulatory follicles. J. Clin. Endocrinol. Metab. 82, 2135-2142.

Chung, J.Y., Song, Y., Wang, Y., Magness, R.R., Zheng, J., 2004. Differential expression of vascular endothelial growth factor (VEGF), endocrine gland derivedVEGF, and VEGF receptors in human placentas from normal and preeclamptic pregnancies. J. Clin. Endocrinol. Metab. 89, 2484- 2490.

Cocks, H.C., Ramsden, J.D., Watkinson, J.C., Eggo, M.C., 2000. Thyroid stimulating hormone increases angiogenic growth factor expression in rat thyrocytes. Clin. Otolaryngol. Allied. Sci. 25, 570-576.

Collin, O., Bergh, A., 1996. Leydig cells secrete factors which increase vascular permeability and endothelial cell proliferation. Int. J. Androl. 19, 221-228.

Cooper, J.C., Sharkey, A.M., McLaren, J., Charnock-Jones, D.S., Smith, S.K., 1995. Localization of vascular endothelial growth factor and its receptor, flt, in human placenta and decidua by immunohistochemistry. J. Reprod Fertil. 105, 205-213.

Csaba, G., Shahin, M.A., Dobozy, O., 1980. Effect of combined gonadotropinthyrotropin treatment on development of testis and ovarium in the chickling. Acta. Physiol. Acad. Sci. Hung. 55, 163-168.

Dancis, J., Jansen, V., Brown, G.F., Gorstein, F., Balis, M.E., 1977. Treatment of hypoplastic anemia in mice with placental transplants. Blood 50, 663-670.

Demir, R., Kaufmann, P., Castellucci, M., Erbengi, T., Kotowski, A., 1989. Fetal vasculogenesis and angiogenesis in human placental villi. Acta. Anat. 136, 190-203.

Demir, R., Kayisli, U.A., Seval, Y., Celik-Ozenci, C., Korgun, E.T., Demir-Weusten, A.Y., Huppertz, B., 2004. Sequential expression of VEGF and its receptors in human placental villi during very early pregnancy: differences between placental vasculogenesis and angiogenesis. Placenta 25, 560-572.

Drenkhahn, M., Gescher, D.M., Wolber, E.M., Meyhoefer-Malik, A., Malik, E., 2004. Expression of angiopoietin 1 and 2 in ectopic endometrium on the chicken chorioallantoic membrane. Fertil. Steril. Suppl 1, 869-875.

Dufau, M.L., 1998. The luteinizing hormone receptor. Annu. Rev. Physiol. 60, 461-496.

Dvorak, H.F., Sioussat, T.M., Brown, L.F., Berse, B., Nagy, J.A., Sotrel, A., Manseau, E.J., Van de Water, L., Senger, D.R., 1991. Distribution of vascular permeability factor (vascular endothelial growth factor) in tumors: concentration in tumor blood vessels. J. Exp. Med. 174, 1275-1278. 
Dvorak, H.F., Brown, L.F., Detmar, M., Dvorak, A.M., 1995. Vascular permeability factor/vascular endothelial growth factor, microvascular hyperpermeability, and angiogenesis. Am. J. Pathol. 146, 1029-1039.

Ergun, S., Kilic, N., Fiedler, W., Mukhopadhyay, A.K., 1997. Vascular endothelial growth factor and its receptors in normal human testicular tissue. Mol. Cell. Endocrinol. 4, 9-20.

European Recombinant LH Study Group, 2001. Human recombinant luteinizing hormone is as effective as, but safer than, urinary human chorionic gonadotropin in inducing final follicular maturation and ovulation in in vitro fertilization procedures: results of a multicenter double-blind study. Clin. Endocrinol. Metab. 86, 2607-2618.

Fasciani, A., D'Ambrogio, G., Bocci, G., Monti, M., Genazzani, A.R., Artini, P.G., 2000. High concentrations of the vascular endothelial growth factor and interleukin-8 in ovarian endometriomata. Mol. Hum. Reprod. 6, 50-54.

Ferenczy, A., Bertrand, G., Gelfand, M.M., 1979. Proliferation kinetics of human endometrium during the normal menstrual cycle. Am. J. Obstet Gynecol. 15, 859867.

Ferrara, N., Carver-Moore, K., Chen, H., Dowd, M., Lu, L., O’Shea, K.S., PowellBraxton, L., Hillan, K.J., Moore, M.W., 1996. Heterozygous embryonic lethality induced by targeted inactivation of the VEGF gene. Nature 380, 435-439.

Ferrara, N., Chen, H., Davis-Smyth, T., Gerber, H.P., Nguyen, T.N., Peers, D., Chisholm, V., Hillan, K.J., Schwall, R.H., 1998. Vascular endothelial growth factor is essential for corpus luteum angiogenesis. Nat. Med. 4, 336-340.

Ferrara, N. 1999. Role of vascular endothelial growth factor in the regulation of angiogenesis. Kidney Int. 56, 794-814.

Fisher, S.J., 2000. The placenta dilemma. Semin. Reprod. Med. 18, 321-326.

Ford, S.P., Chenault, J.R., 1981. Blood flow to the corpus luteum-bearing ovary and ipsilateral uterine horn of cows during the oestrous cycle and early pregnancy. J. Reprod. Fertil. 62, 555-562.

Fraser, H.M., Dickson, S.E., Lunn, S.F., Wulff, C., Morris, K.D., Carroll, V.A., Bicknell, R., 2000. Suppression of luteal angiogenesis in the primate after neutralization of vascular endothelial growth factor. Endocrinology. 141, 995-1000.

Fraser, H.M., Wilson, H., Morris, K.D., Swanston, I., Wiegand, S.J., 2005. Vascular Endothelial Growth Factor Trap Suppresses Ovarian Function at All Stages of the Luteal Phase in the Macaque. J.Clin. Endocrinol. Metab. 90, 5811-5818.

Friedman, S.A., de Groot, C.J., Taylor, R.N., Golditch, B.D., Roberts, J.M., 1994. Plasma cellular fibronectin as a measure of endothelial involvement in preeclampsia and intrauterine growth retardation. Am. J. Obstet. Gynecol. 170, 838-841. 
Galazios, G., Papazoglou, D., Giagloglou, K., Vassaras, G., Koutlaki, N., Maltezos, E., 2004. Umbilical cord serum vascular endothelial growth factor (VEGF) levels in normal pregnancies and in pregnancies complicated by preterm delivery or preeclampsia. Int. J. Gynaecol. Obstet. 85, 6-11.

Garrido, N., Albert,C., Krussel, J.S., O'Connor, J.E., Remohi, J., Simon, C., Pellicer, A., 2001. Expression, production, and secretion of vascular endothelial growth factor and interleukin-6 by granulosa cells is comparable in women with and without endometriosis. Fertil. Steril. 76, 568-575.

Geesaman, B., Villanueva-Meyer, J., Bluestein, D., Miller, L., Mena, I., Rajfer, J., 1992. Effects of multiple injections of HCG on testis blood flow. Urology 40, 81-83.

Gether, U., 2000. Uncovering molecular mechanisms involved in activation of G protein-coupled receptors. Endocr. Rev.21, 90-113.

Geva, E., Jaffe, R.B., 2000. Role of vascular endothelial growth factor in ovarian physiology and pathology. Fertil. Steril. 74, 429-438.

Geva, E., Ginzinger, D.G., Zaloudek, C.J., Moore, D.H., Byrne, A., Jaffe, R.B., 2002. Human placental vascular development: vasculogenic and angiogenic (branching and nonbranching) transformation is regulated by vascular endothelial growth factor-A, angiopoietin-1, and angiopoietin-2. J .Clin. Endocrinol. Metab. 87, 4213-4224.

Giles, W.B., Trudinger, B.J, Cook, C.M., 1985. Fetal umbilical artery flow velocitytime waveforms in twin pregnancies. Br. J. Obstet. Gynaecol. 92, 490-497.

Goede, V., Schmidt, T., Kimmina, S., Kozian, D., Augustin, H.G., 1998. Analysis of blood vessel maturation processes during cyclic ovarian angiogenesis. Lab. Invest. 78, 1385-1394.

Gomez, R., Simon, C., Remoh,i J., Pellicer, A., 2003. Administration of moderate and high doses of gonadotropins to female rats increases ovarian vascular endothelial growth factor (VEGF) and VEGF receptor-2 expression that is associated to vascular hyperpermeability. Biol. Reprod. 68, 2164-2171.

Gomez, R., Lima, I., Simon, C., Pellicer, A., 2004. Administration of low-dose LH induces ovulation and prevents vascular hyperpermeability and vascular endothelial growth factor expression in superovulated rats. Reproduction 127, 483-489.

Grasso, P., Crisp, T.M., 1985. In vitro responses of luteinizing rat granulosa cells to human thyroid-stimulating hormone. Biol. Reprod. 32, 935-945.

Greenwald, G.S., 1989. Temporal and topographic changes in DNA synthesis after induced follicular atresia. Biol. Reprod. 41, 175-181.

Haggstrom Rudolfsson, S., Johansson, A., Franck Lissbrant, I., Wikstrom, P., Bergh, A., 2003. Localized expression of angiopoietin 1 and 2 may explain unique characteristics of the rat testicular microvasculature. Biol. Reprod. 69, 1231-1237. 
Hayes, A.J., Huang, W.Q., Mallah, J., Yang, D., Lippman, M.E., Li, L.Y., 1999. Angiopoietin-1 and its receptor Tie-2 participate in the regulation of capillary-like tubule formation and survival of endothelial cells. Microvasc. Res. 58, 224-237.

Hazzard , T.M., Molskness, T.A., Chaffin, C.L., Stouffer, R.L., 1999. Vascular endothelial growth factor (VEGF) and angiopoietin regulation by gonadotrophin and steroids in macaque granulosa cells during the peri-ovulatory interval. Mol. Hum. Reprod. 5, 1115-1121.

Hazzard, T.M., Xu, F., Stouffer, R.L., 2002. Injection of soluble vascular endothelial growth factor receptor 1 into the preovulatory follicle disrupts ovulation and subsequent luteal function in rhesus monkeys. Biol. Reprod. 67, 1305-1312.

Helske, S., Vuorela, P., Carpen, O., Hornig, C., Weich, H., Halmesmaki, E., 2001. Expression of vascular endothelial growth factor receptors 1, 2 and 3 in placentas from normal and complicated pregnancies. Mol. Hum. Reprod. 7, 205-210.

Hermsteiner, M., Zoltan, D.R., Doetsch, J., Rascher, W., Kuenzel, W., 1999. Human chorionic gonadotropin dilates uterine and mesenteric resistance arteries in pregnant and nonpregnant rats. Pflugers. Arch. 439, 186-194.

Hiratsuka, S., Minowa, O., Kuno, J., Noda, T., Shibuya, M., 1998. Flt-1 lacking the tyrosine kinase domain is sufficient for normal development and angiogenesis in mice. Proc. Natl. Acad. Sci. U. S. A. 95, 9349-954.

Hoffmann, S., Hofbauer, L.C., Scharrenbach, V., Wunderlich, A., Hassan, I., Lingelbach, S., Zielke, A., 2004. Thyrotropin (TSH)-induced production of vascular endothelial growth factor in thyroid cancer cells in vitro: evaluation of TSH signal transduction and of angiogenesis-stimulating growth factors. J. Clin. Endocrinol. Metab. 89, 6139-6145.

Huang, S.C., Hwang, J.L., Hsieh, C.Y., Chen, R.J., Ouyang, P.C., 1989. Human chorionic gonadotropin and its subunits in pre-eclampsia. Yi. Xue. Hui. Za. Zhi. 88, 132-136. 
Hsu, C.D., Chan, D.W., Iriye, B., Johnson, T.R., Hong, S.F., Repke, J.T., 1994. Elevated serum human chorionic gonadotropin as evidence of secretory response in severe preeclampsia. Am. J. Obstet. Gynecol. 170, 1135-1138.

Huber, A.V., Huber, J.C., Kolbus, A., Imhof, M., Nagele, F., Loizou, D., Kaufmann, U., Singer, C.F., 2004. Systemic HCG treatment in patients with endometriosis: a new perspective for a painful disease. Wien. Klein. Wochenschr. 116, 839-843.

Huhtaniemi, I., 2000. The Parkes lecture. Mutations of gonadotrophin and gonadotrophin receptor genes: what do they teach us about reproductive physiology? J. Reprod. Fertil. 119, 173-186.

Huminiecki, L., Chan, H.Y., Lui, S., Poulsom, R., Stamp, G., Harris, A.L., Bicknell, R., 2001. Vascular endothelial growth factor transgenic mice exhibit reduced male fertility and placental rejection. Mol. Hum. Reprod. 7, 255-264.

Iitaka, M., Miura, S., Yamanaka, K., Kawasaki, S., Kitahama, S., Kawakami, Y., Kakinuma, S., Oosuga, I., Wada, S., Katayama, S., 1998. Increased serum vascular endothelial growth factor levels and intrathyroidal vascular area in patients with Graves' disease and Hashimoto's thyroiditis. J. Clin. Endocrinol. Metab. 83, 39083912.

Illera, J.C., Silvan, G., Illera, M.J., Munro, C.J., Lessey, B.A., Illera, M., 2001. Measurement of serum and peritoneal fluid LH concentrations as a diagnostic tool for human endometriosis. Reproduction 121, 761-769.

Ishikawa, K., Ohba, T., Tanaka, N., Iqbal, M., Okamura, Y., Okamura, H., 2003. Organ-specific production control of vascular endothelial growth factor in ovarian hyperstimulation syndrome-model rats. Endocr. J. 50, 515-525.

Islami, D., Bischof, P., Chardonnens, D., 2003. Modulation of placental vascular endothelial growth factor by leptin and hCG. Mol. Hum. Reprod. 9, 395-398.

Jaffe, R., 1998. First trimester utero-placental circulation: maternal-fetal interaction. J. Perinat. Med. 26, 168-174.

Janson, P.O., 1975. Effects of the luteinizing hormone on blood flow in the follicular rabbit ovary, as measured by radioactive microspheres. Acta. Endocrinol. 79, 122133.

Jauniaux, E., Burton, G.J., Moscoso, G.J., Hustin, J., 1991. Development of the early human placenta: a morphometric study. Placenta 12, 269-276.

Jones, C.J., Fox, H., 1980. An ultrastructural and ultrahistochemical study of the human placenta in maternal pre-eclampsia. Placenta. 1, 61-76. 
Kelton, C.A., Cheng, S.V., Nugent, N.P., Schweickhardt, R.L., Rosenthal, J.L., Overton, S.A., Wands, G.D., Kuzeja, J.B., Luchette, C.A., Chappel, S.C., 1992. The cloning of the human follicle stimulating hormone receptor and its expression in COS-7, CHO, and Y-1 cells. Mol. Cell. Endocrinol. 89, 141-151.

Khaliq, A., Dunk, C., Jiang, J., Shams, M., Li, X.F., Acevedo, C., Weich, H., Whittle, M., Ahmed, A., 1999. Hypoxia down-regulates placenta growth factor, whereas fetal growth restriction up-regulates placenta growth factor expression: molecular evidence for "placental hyperoxia" in intrauterine growth restriction. Lab. Invest. 79, 151-170.

Kingdom, J.C., Kaufmann, P.,1999. Oxygen and placental vascular development. Adv. Exp. Med. Biol. 474, 259-275.

Koga, K., Osuga, Y., Yoshino, O., Hirota, Y., Ruimeng, X., Hirata, T., Takeda, S., Yano, T., Tsutsumi, O., Taketani, Y., 2003. Elevated serum soluble vascular endothelial growth factor receptor 1 (sVEGFR-1) levels in women with preeclampsia. J. Clin. Endocrinol. Metab. 88, 2348-2351.

Kupferminc, M.J., Daniel, Y., Englender, T., Baram, A., Many, A., Jaffa, A.J., Gull, I., Lessing, J.B., 1997. Vascular endothelial growth factor is increased in patients with preeclampsia. Am. J. Reprod. Immunol. 38, 302-306.

Lam, P.M., Briton-Jones, C., Cheung, C.K., Lok, I.H., Yuen, P.M., Cheung, L.P., Haines, C., 2003. Vascular endothelial growth factor in the human oviduct: localization and regulation of messenger RNA expression in vivo. Biol Reprod. 68, 1870-1876.

Larijani, B., Marsoosi, V., Aghakhani, S., Moradi, A., Hashemipour, S., 2004. Thyroid hormone alteration in pre-eclamptic women. Gynecol. Endocrinol. 18, 97-100.

Laschke, M.W., Elitzsch, A., Vollmar, B., Vajkoczy, P., Menger, M.D., 2005. Combined inhibition of vascular endothelial growth factor (VEGF), fibroblast growth factor and platelet-derived growth factor, but not inhibition of VEGF alone, effectively suppresses angiogenesis and vessel maturation in endometriotic lesions. Hum. Reprod. (in press).

Lash, G., MacPherson, A., Liu, D., Smith, D., Charnock-Jones, S., Baker, P., 2001. Abnormal fetal growth is not associated with altered chorionic villous expression of vascular endothelial growth factor mRNA. Mol. Hum. Reprod. 7, 1093-1098. 
LeCouter, J., Lin, R., Ferrara, N., 2002. Endocrine gland-derived VEGF and the emerging hypothesis of organ-specific regulation of angiogenesis. Nat. Med. 8, 913917.

Lee, A., Christenson, L.K., Stouffer, R.L., Burry, K.A., Patton, P.E., 1997. Vascular endothelial growth factor levels in serum and follicular fluid of patients undergoing in vitro fertilization. Fertil. Steril. 68, 305-311.

Lei, Z.M., Reshef, E., Rao, V., 1992. The expression of human chorionic gonadotropin/luteinizing hormone receptors in human endometrial and myometrial blood vessels. J. Clin. Endocrinol. Metab. 75, 651-659.

Lei, Z.M., Rao,C.V., Kornyei, J.L., Licht, P., Hiatt, E.S., 1993. Novel expression of human chorionic gonadotropin/luteinizing hormone receptor gene in brain. Endocrinology 132, 2262-2270.

Lei, Z.M., Mishra, S., Zou, W., Xu, B., Foltz, M., Li, X., Rao, C.V., 2001. Targeted disruption of luteinizing hormone/human chorionic gonadotropin receptor gene. Mol. Endocrinol. 15, 184-200.

Lei, Z.M., Zou, W., Mishra, S., Li, X., Rao, Ch.V., 2003. Epididymal phenotype in luteinizing hormone receptor knockout animals and its response to testosterone replacement therapy. Biol. Reprod. 68, 888-895.

Licht, P., Russu, V., Lehmeyer, S., Wildt, L., 2001. Molecular aspects of direct LH/hCG effects on human endometrium--lessons from intrauterine microdialysis in the human female in vivo. Reprod. Biol. 1, 10-19.

Licht, P., von Wolff, M., Berkholz, A., Wildt, L., 2003. Evidence for cycle-dependent expression of full-length human chorionic gonadotropin/luteinizing hormone receptor mRNA in human endometrium and decidua. Fertil. Steril. 79, 718-723.

Lockwood, C.J., Peters, J.H., 1990. Increased plasma levels of ED1+ cellular fibronectin precede the clinical signs of preeclampsia. Am. J. Obstet. Gynecol. 162, 358-362.

Lyall, F., Young, A., Boswell, F., Kingdom, J.C., Greer, I.A., 1997. Placental expression of vascular endothelial growth factor in placentae from pregnancies complicated by pre-eclampsia and intrauterine growth restriction does not support placental hypoxia at delivery. Placenta 18, 269-276.

Macara, L., Kingdom, J.C., Kaufmann, P., Kohnen, G., Hair, J., More, I.A., Lyall, F., Greer, I.A., 1996. Structural analysis of placental terminal villi from growthrestricted pregnancies with abnormal umbilical artery Doppler waveforms. Placenta $17,37-48$. 
McElhinney, B., Ardill, J., Caldwell, C., McClure, N., 2003. Preventing ovarian hyperstimulation syndrome by inhibiting the effects of vascular endothelial growth factor. J. Reprod. Med. 48, 243-246.

Matsumoto, T., Claesson-Welsh, L., 2001. VEGF receptor signal transduction. Sci. STKE. RE21.

Matzuk, M.M., DeMayo, F.J., Hadsell, L.A., Kumar, T.R., 2003. Overexpression of human chorionic gonadotropin causes multiple reproductive defects in transgenic mice. Biol. Reprod. 69, 338-346.

Mayhew, T.M., 2003. Changes in fetal capillaries during preplacental hypoxia: growth, shape remodelling and villous capillarization in placentae from high-altitude pregnancies. Placenta 24, 191-198.

Maynard, S.E., Min, J.Y., Merchan, J., Lim, K.H., Li, J., Mondal, S., Libermann, T.A., Morgan, J.P., Sellke, F.W., Stillman, I.E., Epstein, F.H., Sukhatme, V.P., Karumanchi, S.A., 2003. Excess placental soluble fms-like tyrosine kinase 1 (sFlt1) may contribute to endothelial dysfunction, hypertension, and proteinuria in preeclampsia. J. Clin. Invest. 111, 649-658.

Melchers, F., 1979. Murine embryonic B lymphocyte development in the placenta. Nature 18, 219-221.

Merviel, P., Muller, F., Guibourdenche, J., Berkane, N., Gaudet, R., Breart, G., Uzan, S., 2001. Correlations between serum assays of human chorionic gonadotrophin (hCG) and human placental lactogen (hPL) and pre-eclampsia or intrauterine growth restriction (IUGR) among nulliparas younger than 38 years. Eur. J. Obstet. Gynecol. Reprod. Biol. 95, 59-67.

Mikic, T.S., Johnson, P., 1999. Second trimester maternal serum beta human chorionic gonadotrophin and pregnancy outcome. Br. J. Obstet. Gynaecol. 106, 598-600.

Mikkola, H.K., Gekas, C., Orkin, S.H., Dieterlen-Lievre, F., 2005. Placenta as a site for hematopoietic stem cell development. Exp. Hematol. 33, 1048-1054.

Minatami, H., Takahashi, T., Izumi, A., Tamada, T., 1993. Increased levels of plasma thrombomodulin in preeclampsia. Gynecol. Obstet. Invest. 36, 208-210.

Minegishi, T., Nakamura, K., Takakura, Y., Ibuki, Y., Igarashi, M., Minegishi, T., 1991. Cloning and sequencing of human FSH receptor cDNA. Biochem. Biophys. Res. Commun. 175, 1125-1130.

Nagayama, Y., Russo, D., Wadsworth, H.L., Chazenbalk, G.D., Rapoport, B., 1991. Eleven amino acids (Lys-201 to Lys-211) and 9 amino acids (Gly-222 to Leu-230) in the human thyrotropin receptor are involved in ligand binding. J. Biol. Chem. 266, 14926-1430.

Nap, A.W., Dunselman, G.A., Griffioen, A.W., Mayo, K.H., Evers, J.L., Groothuis, P.G., 2005. Angiostatic agents prevent the development of endometriosis-like lesions in the chicken chorioallantoic membrane. Fertil. Steril. 83, 793-5. 
Neulen, J., Yan, Z., Raczek, S., Weindel, K., Keck, C., Weich, H.A., Marme, D., Breckwoldt, M., 1995. Human chorionic gonadotropin-dependent expression of vascular endothelial growth factor/vascular permeability factor in human granulosa cells: importance in ovarian hyperstimulation syndrome. Clin. Endocrinol. Metab. 80, 1967-1971.

Odell, W., Wolfsen, A., Yoshimoto, Y., Weitzman, R., Fisher, D., Hirose, F., 1977. Ectopic peptide synthesis: a universal concomitant of neoplasia. Trans. Assoc. Am. Physicians. 90, 204-227.

Oktay, K., Briggs, D., Gosden, R.G., 1997. Ontogeny of follicle-stimulating hormone receptor gene expression in isolated human ovarian follicles. J. Clin. Endocrinol. Metab. 82, 3748-3751.

Otani, N., Minami, S., Yamoto, M., Shikone, T., Otani, H., Nishiyama, R., Otani. T., Nakano, R., 1999. The vascular endothelial growth factor/fms-like tyrosine kinase system in human ovary during the menstrual cycle and early pregnancy. J. Clin. Endocrinol. Metab. 84, 3845-3851.

Ottersbach, K., Dzierzak, E., 2005. The murine placenta contains hematopoietic stem cells within the vascular labyrinth region. Dev. Cell. 8, 377-387.

Pabon, J.E., Bird, J.S., Li, X., Huang, Z.H., Lei, Z.M., Sanfilippo, J.S., Yussman, M.A., Rao, C.V., 1996. Human skin contains luteinizing hormone/chorionic gonadotropin receptors. J. Clin. Endocrinol. Metab. 81, 2738-2741.

Pellicer, A., Albert, C., Mercader, A., Bonilla-Musoles, F., Remoti, J., Simon, C., 1998. The follicular and endocrine environment in women with endometriosis: local and systemic cytokine production. Fertil. Steril. 70, 425-431.

Peters, H., Byskov, A.G., Grinsted, J., 1978. Follicular growth in fetal and prepubertal ovaries of humans and other primates. Clin. Endocrinol. Metab. 7, 469-485.

Phillips, D.J., Wide, L., 1994. Serum gonadotropin isoforms become more basic after an exogenous challenge of gonadotropin-releasing hormone in children undergoing pubertal development. J. Clin. Endocrinol. Metab. 79, 814-819.

Policastro, P.F., Daniels-McQueen, S., Carle, G., Boime, I., 1986. A map of the hCG beta-LH beta gene cluster. J. Biol. Chem. 261, 5907-5916.

Poteri, G., Lucarini, G., Filona, A., Pierantoni, A., Montik, N., Bigini, G., Fabris, G., Ciavattini, A. 2004. Immunohistochemical analysis of vascular endothelial growth factor cellular expression in ovarian endometriomata. Fertil. Steril. 81, 1528-1533.

Poppe, K., Glinoer, D., Van Steirteghem, A., Tournaye, H., Devroey, P., Schiettecatte, J., Velkeniers, B., 2002. Thyroid dysfunction and autoimmunity in infertile women. Thyroid 12, 997-1001. 
Qublan, H.S., Al-Kaisi, I.J., Hindawi, I.M., Hiasat, M.S., Awamleh, I., Hamaideh, A.H., Abd-Alghani, I., Sou'ub, R.M., Abu-Jassar, H., Al-Maitah, M., 2003. Severe preeclampsia and maternal thyroid function. J. Obstet. Gynaecol. 23, 244-246.

Rahimi, N., Dayanir, V., Lashkari, K., 2000. Receptor chimeras indicate that the vascular endothelial growth factor receptor-1 (VEGFR-1) modulates mitogenic activity of VEGFR-2 in endothelial cells. J. Biol. Chem. 275, 16986-16992.

Rajakumar, A., Michael, H.M., Rajakumar, P.A., Shibata, E., Hubel, C.A., Karumanchi, S.A., Thadhani, R., Wolf, M., Harger, G., Markovic, N., 2005. Extra-placental expression of vascular endothelial growth factor receptor-1, (Flt-1) and soluble Flt-1 (sFlt-1), by peripheral blood mononuclear cells (PBMCs) in normotensive and preeclamptic pregnant women. Placenta 26, 563-573.

Ramsden, J.D., Cocks, H.C., Shams, M., Nijjar, S., Watkinson, J.C., Sheppard, M.C., Ahmed, A., Eggo, M.C., 2001. Tie-2 is expressed on thyroid follicular cells, is increased in goiter, and is regulated by thyrotropin through cyclic adenosine 3',5'monophosphate. J. Clin. Endocrinol. Metab. 86, 2709-2716.

Ravindranath, N., Little-Ihrig, L., Phillips, H.S., Ferrara, N., Zeleznik, A.J., 1992. Vascular endothelial growth factor messenger ribonucleic acid expression in the primate ovary. Endocrinology 131, 254-260.

Redline, R.W., Patterson, P., 1995. Pre-eclampsia is associated with an excess of proliferative immature intermediate trophoblast. Hum. Pathol. 26, 594-600.

Redman, C.W., 1991. Current topic: pre-eclampsia and the placenta. Placenta 12, 301308.

Redmer, D.A., Reynolds, L.P., 1996. Angiogenesis in the ovary. Rev. Reprod. 1, 182192.

Redmer, D.A., Doraiswamy, V., Bortnem, B.J., Fisher, K., Jablonka-Shariff, A., GrazulBilska, A.T., Reynolds, L.P., 2001. Evidence for a role of capillary pericytes in vascular growth of the developing ovine corpus luteum. Biol. Reprod. 65, 879-889.

Regnault, T.R., Galan, H.L., Parker, T.A., Anthony, R.V., 2002. Placental development in normal and compromised pregnancies-- a review. Placenta Suppl A, S119-29.

Reiter, E., McNamara, M., Closset, J., Hennen, G., 1995. Expression and functionality of luteinizing hormone/chorionic gonadotropin receptor in the rat prostate. Endocrinology 136, 917-923.

Reshef, E., Lei, Z.M., Rao, C.V., Pridham, D.D., Chegini, N., Luborsky, J.L., 1990. The presence of gonadotropin receptors in nonpregnant human uterus, human placenta, fetal membranes, and decidua. J. Clin. Endocrinol. Metab. 70, 421-430.

Reuvekamp, A., Velsing-Aarts, F.V., Poulina, I.E., Capello, J.J., Duits, A.J., 1999. Selective deficit of angiogenic growth factors characterises pregnancies complicated by pre-eclampsia. Br. J. Obstet. Gynaecol. 106, 1019-1022. 
Reynolds, L.P., Grazul-Bilska, A.T., Killilea, S.D., Redmer, D.A., 1994. Mitogenic factors of corpora lutea. Prog. Growth. Factor. Res. 5, 159-175.

Reynolds, L.P., Redmer, D.A., 1995. Utero-placental vascular development and placental function. J. Anim. Sci. 73, 1839-1851.

Reynolds, L.P., Grazul-Bilska, A.T., Redmer, D.A., 2000. Angiogenesis in the corpus luteum. Endocrine 12, 1-9.

Richards, J.S., Hedin, L., 1988. Molecular aspects of hormone action in ovarian follicular development, ovulation, and luteinization. Annu. Rev. Physiol. 50, 441463.

Roberts, W.G., Palade, G.E., 1995. Increased microvascular permeability and endothelial fenestration induced by vascular endothelial growth factor. J. Cell. Sci. 108, 2369-2379.

Roberts, J.M., 1998. Endothelial dysfunction in preeclampsia. Semin. Reprod. Endocrinol. 16, 5-15.

Rowe, A.J., Wulff, C., Fraser, H.M., 2003. Localization of mRNA for vascular endothelial growth factor (VEGF), angiopoietins and their receptors during the periimplantation period and early pregnancy in marmosets (Callithrix jacchus). Reproduction 126, 227-238.

Rudolfsson, S.H., Wikstrom, P., Jonsson, A., Collin, O., Bergh, A., 2004. Hormonal regulation and functional role of vascular endothelial growth factor a in the rat testis. Biol. Reprod. 70, 340-347.

Saez, J.M., 1994. Leydig cells: endocrine, paracrine, and autocrine regulation. Endocr. Rev. 15, 574-626.

Shahin, M.A., Csaba, G., Dobozy, O., 1980. Effect of gonadotropins and thyrotropin on the testes and ovaries of the newly hatched chicken. Acta. Morphol. Acad. Sci. Hung. 28, 317-335.

Salaria, C.M., Pezzullo, J.C., Minior, V.K., Divon, M.Y., 1997. Placental pathology of absent and reversed end-diastolic flow in growth-restricted fetuses. Obstet. Gynecol. 90, 830-836.

Sato, K., Yamazaki, K., Shizume, K., Kanaji, Y., Obara, T., Ohsumi, K., Demura, H., Yamaguchi, S., Shibuya, M., 1995. Stimulation by thyroid-stimulating hormone and Grave's immunoglobulin $G$ of vascular endothelial growth factor mRNA expression in human thyroid follicles in vitro and flt mRNA expression in the rat thyroid in vivo. J. Clin. Invest. 96, 1295-1302.

Schams D, Kosmann M, Berisha B, Amselgruber WM, Miyamoto A., 2001. Stimulatory and synergistic effects of luteinising hormone and insulin like growth factor 1 on the secretion of vascular endothelial growth factor and progesterone of cultured bovine granulosa cells. Exp. Clin. Endocrinol. Diabetes 109,155-162. 
Schwarzenbach, H., Chakrabarti, G., Paust, H.J., Mukhopadhyay, A.K., 2004. Gonadotropin-mediated regulation of the murine VEGF expression in MA-10 Leydig cells. J. Androl. 25, 128-139.

Segaloff, D.L., Ascoli, M., 1993. The lutropin/choriogonadotropin receptor ... 4 years later. Endocr. Rev14, 324-347.

Setchell, B.P., Sharpe, R.M., 1981. Effect of injected human chorionic gonadotrophin on capillary permeability, extracellular fluid volume and the flow of lymph and blood in the testes of rats. J. Endocrinol. 91, 245-254.

Shaarawy, M., Al-Sokkary, F., Sheba, M., Wahba, O., Kandil, H.O., Abdel-Mohsen, I., 2005. Angiogenin and vascular endothelial growth factor in pregnancies complicated by preeclampsia. Int. J. Gynaecol. Obstet. 88, 112-117.

Sharkey, A.M., Charnock-Jones, D.S., Boocock, C.A., Brown, K.D., Smith, S.K., 1993. Expression of mRNA for vascular endothelial growth factor in human placenta. J. Reprod. Fertil. 99, 609-615.

Sharpe, R.M., 1993. Declining sperm counts in men--is there an endocrine cause? J. Endocrinol. 136, 357-360.

Shifren, J.L., Tseng, J.F., Zaloudek, C.J., Ryan, I.P., Meng, Y.G., Ferrara, N., Jaffe, R.B., Taylor, R.N., 1996. Ovarian steroid regulation of vascular endothelial growth factor in the human endometrium: implications for angiogenesis during the menstrual cycle and in the pathogenesis of endometriosis. J. Clin. Endocrinol. Metab. 81, 31123118.

Shweiki, D., Itin, A., Neufeld, G., Gitay-Goren, H., Keshet, E., 1993. Patterns of expression of vascular endothelial growth factor (VEGF) and VEGF receptors in mice suggest a role in hormonally regulated angiogenesis. J. Clin. Invest. 91, 22352243.

Simoni, M., Gromoll, J., Nieschlag, E., 1997. The follicle-stimulating hormone receptor: biochemistry, molecular biology, physiology, and pathophysiology. Endocr. Rev. 18, 739-773.

Soh, E.Y., Sobhi, S.A., Wong, M.G., Meng, Y.G., Siperstein, A.E., Clark, O.H., Duh, Q.Y., 1996. Thyroid-stimulating hormone promotes the secretion of vascular endothelial growth factor in thyroid cancer cell lines. Surgery 120, 944-947.

Sorvillo, F., Mazziotti, G., Carbone, A., Piscopo, M., Rotondi, M., Ciuffi, M., Musto, P., Biondi, B., Iorio, S., Amato, G., Carella, C., 2003. Recombinant human thyrotropin reduces serum vascular endothelial growth factor levels in patients monitored for thyroid carcinoma even in the absence of thyroid tissue. J. Clin. Endocrinol. Metab. 88, 4818-4822. 
Staff, A.C., Braekke, K., Harsem, N.K., Lyberg, T., Holthe, M.R., 2005. Circulating concentrations of sFlt1 (soluble fms-like tyrosine kinase 1) in fetal and maternal serum during pre-eclampsia. Eur. J. Obstet. Gynecol. Reprod. Biol. 122, 33-39.

Starzyk, K.A., Salafia, C.M., Pezzullo, J.C., Lage, J.M., Parkash, V., Vercruysse, L., Hanssens, M., Pijnenborg, R., 1997. Quantitative differences in arterial morphometry define the placental bed in preeclampsia. Hum. Pathol. 28, 353-358.

Starzyk, K.A., Pijnenborg, R., Salafia, C.M., 1999. Decidual and vascular pathophysiology in pregnancy compromise. Semin. Reprod. Endocrinol. 17, 63-72.

Suri, C., McClain, J., Thurston, G., McDonald, D.M., Zhou, H., Oldmixon, E.H., Sato, T.N., Yancopoulos, G.D., 1998. Increased vascularization in mice overexpressing angiopoietin-1. Science 282, 468-471.

Szukiewicz, D., Szewczyk ,G., Watroba, M., Kurowska, E., Maslinski, S., 2004. Isolated placental vessel response to vascular endothelial growth factor and placenta growth factor in normal and growth-restricted pregnancy. Gynecol. Obstet. Invest. $59,102-107$.

Takehara, M., Ueda, M., Yamashita, Y., Terai, Y., Hung, Y.C., Ueki. M., 2004. Vascular endothelial growth factor $\mathrm{A}$ and $\mathrm{C}$ gene expression in endometriosis. Hum. Pathol. 35, 1369-1375.

Tao, Y.X., Lei, Z.M., Woodworth, S.H., Rao, C.V., 1995. Novel expression of luteinizing hormone/chorionic gonadotropin receptor gene in rat prostates. Mol. Cell. Endocrinol. 111, R9-12.

Tao, Y.X., Lei, Z.M., Rao, C.V., 1998. Seminal vesicles are novel sites of luteinizing hormone/human chorionic gonadotropin-receptor gene expression. J. Androl. 19, 343-347.

Taylor, R.N., Crombleholme, W.R., Friedman, S.A., Jones, L.A., Casal, D.C., Roberts, J.M., 1991. High plasma cellular fibronectin levels correlate with biochemical and clinical features of preeclampsia but cannot be attributed to hypertension alone. Am. J. Obstet. Gynecol. 165, 895-901.

Taylor, R.N., de Groot, C.J., Cho, Y.K., Lim, K.H., 1998. Circulating factors as markers and mediators of endothelial cell dysfunction in preeclampsia. Semin. Reprod. Endocrinol. 16, 17-31.

te Velde, E.A., Exalto, N., Hesseling, P., van der Linden, H.C., 1997. First trimester development of human chorionic villous vascularization studied with CD34 immunohistochemistry. Hum. Reprod. 12, 1577-1581.

Themmen, A.P.N., Huhtaniemi, I.T., 2000. Mutations of gonadotropins and gonadotropin receptors: elucidating the physiology and pathophysiology of pituitarygonadal function. Endocr. Rev. 21, 551-583. 
Tilly, J.L., Aihara, T., Nishimori, K., Jia, X.C., Billig, H., Kowalski, K.I., Perlas, E.A., Hsueh, A.J., 1992. Expression of recombinant human follicle-stimulating hormone receptor: species-specific ligand binding, signal transduction, and identification of multiple ovarian messenger ribonucleic acid transcripts. Endocrinology. 131, 799806.

Thorp, J.M. Jr., White, G.C., Moake, J.L., Bowes, W.A. Jr., 1990. von Willebrand factor multimeric levels and patterns in patients with severe preeclampsia. Obstet. Gynecol. 75, 163-167.

Torry, D.S., Hinrichs, M., Torry, R.J., 2004. Determinants of placental vascularity. Am. J. Reprod. Immunol. 51, 257-268.

Toth, P., Li, X., Rao, C.V., Lincoln, S.R., Sanfilippo, J.S, Spinnato, J.A., Yussman, M.A., 1994. Expression of functional human chorionic gonadotropin/human luteinizing hormone receptor gene in human uterine arteries. J .Clin. Endocrinol. Metab. 79, 307-315.

Tsatsaris, V., Goffin, F., Munaut, C., Brichant, J.F., Pignon, M.R., Noel, A., Schaaps, J.P., Cabrol, D., Frankenne, F., Foidart, J.M., 2003. Overexpression of the soluble vascular endothelial growth factor receptor in preeclamptic patients: pathophysiological consequences. J. Clin. Endocrinol. Metab. 88, 5555-5563.

Tuttle, R.M., Fleisher, M., Francis, G.L., Robbins, R.J., 2002. Serum vascular endothelial growth factor levels are elevated in metastatic differentiated thyroid cancer but not increased by short-term TSH stimulation. J. Clin. Endocrinol. Metab. 87, 1737-1742.

Varga, B., Horvath, E., Folly, G., Stark, E., 1985. Study of the luteinizing hormoneinduced increase of ovarian blood flow during the estrous cycle in the rat. Biol. Reprod. 32, 480-488.

Vuckovic, M., Ponting, J., Terman, B.I., Niketic, V., Seif, M.W., Kumar, S., 1996. Expression of the vascular endothelial growth factor receptor, KDR, in human placenta. J.Anat. 188, 361-366.

Vuorela, P., Hatva, E., Lymboussaki, A., Kaipainen, A., Joukov, V., Persico, M.G., Alitalo, K., Halmesmaki, E., 1997. Expression of vascular endothelial growth factor and placenta growth factor in human placenta. Biol. Reprod. 56, 489-494.

Vuorela, P., Lintula, S., Stenman, U.H., Halmesmaki, E., 2003. Expression of vascular endothelial growth factor in peripheral blood cells of preeclamptic women. Hypertens. Pregnancy. 22, 193-201.

Wang, H.B., Lang, J.H., Leng, J.H., Zhu, L., Liu, Z.F., Sun, D.W., 2005. Expression of vascular endothelial growth factor receptors in the ectopic and eutopic endometrium of women with endometriosis. Zhonghua. Yi. Xue. Za. Zhi. 85, 1555-15559. 
Wang, J.F., Milosveski, V., Schramek, C., Fong, G.H., Becks, G.P., Hill, D.J., 1998. Presence and possible role of vascular endothelial growth factor in thyroid cell growth and function. J. Endocrinol. 157, 5-12.

Wenstrom, K.D., Owen, J., Boots, L.R., DuBard, M.B., 1994. Elevated second-trimester human chorionic gonadotropin levels in association with poor pregnancy outcome. Am. J. Obstet. Gynecol. 171, 1038-1041.

Wide, L., Hobson, B.M., 1983. Qualitative difference in follicle-stimulating hormone activity in the pituitaries of young women compared to that of men and elderly women. J. Clin. Endocrinol. Metab. 56, 371-375.

Wide, L., 1989. Follicle-stimulating hormones in anterior pituitary glands from children and adults differ in relation to sex and age. J. Endocrinol. 123, 519-529.

Wijayagunawardane, M.P., Kodithuwakku, S.P., Yamamoto, D., Miyamoto, A., 2005. Vascular endothelial growth factor system in the cow oviduct: A possible involvement in the regulation of oviductal motility and embryo transport. Mol. Reprod. Dev. 72, 511-520.

Wulff, C., Wilson, H., Largue, P., Duncan, W.C., Armstrong, D.G., Fraser, H.M., 2000. Angiogenesis in the human corpus luteum: localization and changes in angiopoietins, tie-2, and vascular endothelial growth factor messenger ribonucleic acid. J. Clin. Endocrinol. Metab. 85, 4302-4309.

Wulff, C., Dickson, S.E., Duncan, W.C., Fraser, H.M., 2001. Angiogenesis in the human corpus luteum: simulated early pregnancy by HCG treatment is associated with both angiogenesis and vessel stabilization. Hum. Reprod. 16, 2515-2524.

Wulff, C., Wilson, H., Wiegand, S.J., Rudge, J.S., Fraser , H.M., 2002. Prevention of thecal angiogenesis, antral follicular growth, and ovulation in the primate by treatment with vascular endothelial growth factor Trap R1R2. Endocrinology 143, 2797-2807.

Wurtman, R.J., 1964. An effect of luteinizing hormone on the fractional perfusion of the rat ovary. Endocrinology 75, 927-933.

Yancopoulos, G.D., Davis, S., Gale, N.W., Rudge, J.S., Wiegand, S.J., Holash, J., 2000. Vascular-specific growth factors and blood vessel formation. Nature 407, 242-248.

Zhang, E.G., Smith, S.K., Baker, P.N., Charnock-Jones, D.S., 2001. The regulation and localization of angiopoietin-1, -2, and their receptor Tie2 in normal and pathologic human placentae. Mol. Med. 7, 624-635.

Zhang, F.P., Poutanen, M., Wilbertz, J., Huhtaniemi, I., 2001. Normal prenatal but arrested postnatal sexual development of luteinizing hormone receptor knockout (LuRKO) mice. Mol. Endocrinol. 15, 172-183. 
Zhang, Y.M., Rao, Ch.V., Lei, Z.M., 2003. Macrophages in human reproductive tissues contain luteinizing hormone/chorionic gonadotropin receptors. Am. J. Reprod. Immunol. 49, 93-100.

Zhou, Y., Fisher, S.J., Janatpour, M., Genbacev, O., Dejana, E., Wheelock, M., Damsky, C.H., 1997. Human cytotrophoblasts adopt a vascular phenotype as they differentiate. A strategy for successful endovascular invasion? J. Clin. Invest. 99, 2139-2151.

Zhou, Y., Bellingard, V., Feng, K.T., McMaster, M., Fisher, S.J., 2003. Human cytotrophoblasts promote endothelial survival and vascular remodeling through secretion of Ang2, PlGF, and VEGF-C. Dev. Biol. 1, 114-125.

Zimmermann, R.C., Xiao, E., Husami, N., Sauer, M.V., Lobo, R., Kitajewski, J., Ferin, M., 2001a. Short-term administration of antivascular endothelial growth factor antibody in the late follicular phase delays follicular development in the rhesus monkey. J. Clin. Endocrinol. Metab. 86, 768-772.

Zimmermann, R.C., Hartman, T., Bohlen, P., Sauer, M.V., Kitajewski, J., 2001b. Preovulatory treatment of mice with anti-VEGF receptor 2 antibody inhibits angiogenesis in corpora lutea. Microvasc. Res. 62, 15-25.

Zygmunt, M., Hahn, D., Munstedt, K., Bischof, P., Lang U., 1998. Invasion of cytotrophoblastic JEG-3 cells is stimulated by hCG in vitro. Placenta 19, 587-593.

Zygmunt, M., Herr, F., Keller-Schoenwetter, S., Kunzi-Rapp, K., Munstedt, K., Rao, C.V., Lang, U., Preissner, K.T., 2002. Characterization of human chorionic gonadotropin as a novel angiogenic factor. J. Clin. Endocrinol. Metab. 87, 529052966.

Zygmunt, M., Herr, F., Munstedt, K., Lang, U., Liang, O.D., 2003. Angiogenesis and vasculogenesis in pregnancy. Eur. J. Obstet. Gynecol. Reprod. Biol. Suppl 1:S10-8.

Zygmunt, M., McKinnon, T., Herr, F., Lala, P.K., Han, V.K., 2005. HCG increases trophoblast migration in vitro via the insulin-like growth factor-II/mannose-6 phosphate receptor. Mol. Hum. Reprod. 11, 261-267. 